Journal of Iberian Geology 42 (3) 2016: 335-354

http://dx.doi.org/10.5209/JIGE.54667

www.ucm.es/info/estratig/journal.htm

\title{
Middle Jurassic volcanism in a magmatic-rich passive margin linked to the Caudiel Fault Zone (Iberian Range, East of Spain): biostratigraphical dating
}

\author{
J.E. Cortés ${ }^{1}$, J.J. Gómez ${ }^{1,2, *}$ \\ ${ }^{1}$ Dpto. de Estratigrafía, Facultad de Ciencias Geológicas, Universidad Complutense de Madrid, 28040 Madrid, Spain \\ ${ }^{2}$ Instituto de Geociencias (CSIC,UCM). c. José Antonio Novais 12, 28040 Madrid, Spain
}

e-mail addresses: jgomez@ucm.es (J.J.G., *Corresponding author); jocortes@ucm.es (J.E.C.)

Received: 1 April 2016 / Accepted: 24 November 2016 / Available online: 20 December 2016

\begin{abstract}
During the Early and Middle Jurassic, the Iberian Basin (East of Spain) recorded the transition from a generally magma-poor passive margin, which operated during the latest Triassic and most of Early Jurassic, to a magma-rich passive margin, developed from Pliensbachian to early Middle Jurassic. The mainly submarine pyroclastic volcanism, with minor lava flows, followed active NW and NE trending extensional fault zones. One of these zones of weakness, from which the volcanic deposits were expelled to the sea bottom, was the Caudiel Fault Zone. Two volcanic phases in relation to this weakness line over the Middle Jurassic times have been identified. The main phase occurred during the deposition of the El Pedregal Formation, and the other, less significant, is included between the Casinos and the El Pedregal formations. So far, the accurate age of these volcanisms, critical in the knowledge of the palaeogeographical and geodynamical evolution of the Iberian Basin, has remained uncertain. The ammonite content of the carbonate successions, with which these rocks are interbedded, allows precise biostratigraphical dating at the chronozone scale. For this purpose, 9 sections have been measured and 360 specimens of ammonites were collected and determined. The obtained data indicate that the Middle Jurassic volcanic deposits that are linked to the Caudiel Fault Zone and included into the El Pedregal Formation show a slight diachrony. They were deposited around the boundary between the Late Aalenian Concavum and the Early Bajocian Discites chronozones. However, in very restricted areas of the Caudiel Fault Zone, an older intra-Murchisonae volcanism was recorded.
\end{abstract}

Keywords: Volcanism, Biochronostratigraphy, Ammonites, Middle Jurassic, Iberian Range

\section{Resumen}

Durante el Jurásico Inferior y Medio, la Cuenca Ibérica (Este de España) registró la transición de un margen pasivo pobre en magmatismo, que operó durante el Triásico terminal y la mayor parte del Jurásico Inferior, a un margen pasivo rico en actividad magmática, que se desarrolló desde el Pliensbachiense hasta el comienzo del Jurásico Medio. El volcanismo submarino, fundamentalmente piroclástico y con flujos de lavas en menor proporción, siguió zonas de falla extensionales activas de orientación NW y NE. Una de estas zonas de debilidad, desde la que los depósitos volcánicos fueron expelidos al fondo del mar, fue la Zona de Falla de Caudiel. Se han identificado dos fases volcánicas que tuvieron lugar a lo largo del Jurásico Medio en relación con esta línea de debilidad. La fase principal se manifestó mientras se producía el depósito de la Formación El Pedregal, pero existió otra, mucho menos significativa, incluida entre la Formación Casinos y la Formación El Pedregal. Hasta el momento, la edad precisa de ambos volcanismos, crítica para conocer la evolución paleogeográfica y geodinámica de la Cuenca Ibérica, ha permanecido incierta. El contenido en ammonites de las sucesiones de carbonatos, entre los que están intercaladas estas rocas, permite la datación bioestratigráfica a nivel de cronozona. Con este propósito se han levantado 9 secciones estratigráficas y se han recolectado y determinado 360 ejemplares de ammonites. Los datos obtenidos indican que los materiales volcánicos del Jurásico Medio que están asociados a la Zona de Falla de Caudiel e incluidos en la Formación El Pedregal muestran una sincronía casi perfecta. Se depositaron hacia el límite entre la Cronozona Concavum del Aaleniense Superior y la Cronozona Discites del Bajociense Inferior. Con anterioridad, un volcanismo de edad intra-Murchisonae quedó registrado en áreas muy localizadas de la Zona de Falla de Caudiel. 


\section{Introduction}

The Iberian Plate occupied during the Jurassic a key position between the Euroasiatic and the African Plates (i.e. Stampfli and Borel, 2002, 2004; Osete et al., 2011; Schettino and Turco, 2011) (Fig.1). The Iberian Basin was at this time an intracratonic basin attached to the east of the Iberian Massif, representing the western boundary of the proto-Ligurian Tethys Ocean (Schettino and Turco, 2011). During the Mesozoic, this basin was repeatedly affected by extensional tectonics (Salas et al., 2001; Ziegler et al., 2001). The Permian and most of the Triassic were dominated by a rifting stage, but the latest Triassic and the Early and Middle Jurassic have been considered as deposited under a post-rift stage (Salas and Casas, 1993; Salas et al., 2001; Sánchez-Moya and Sopeña, 2004) or better as a passive margin stage.

Nevertheless, indications that the Iberian Basin did not behaved as a typical passive margin, dominated by thermal subsidence, have been evidenced by the presence of a network of NW and NE trending synsedimentary faults (i.e., Gómez, 1979; Fernández-López and Gómez, 1990; Goy et al., 1997; Van Wees et al., 1998; García-Frank, 2006; Gómez and Fernández-López, 2006; García-Frank et al., 2006, 2008) (Fig. 2), as well as by the occurrence of significant volcanism, mainly during the Pliensbachian-Bajocian interval.

Except for the scarce subvolcanic dolerites with ophitic and subophitic texture, included as dikes and sills in the Upper Tiassic Keuper facies (Ortí, 2004; Lago et al., 2004), the absence or limited presence of magmatism in the uppermost Triassic and lowermost Jurassic deposits indicate a magma-poor phase during the late rifting and early passive margin stages (Franke, 2013). However, what is notable in this area is the record of the evolution from a magma-poor passive margin to a magma-rich passive margin (Bally, 1982; Nemčok, 2016) over the period from the latest Early Jurassic to the earliest Middle Jurassic.

The presence of volcanic rocks interbedded in the Jurassic deposits of the Iberian Range (Fig. 3) is known since the first half of the 20th century (Bakx, 1935; Martin, 1936). Research works on the presence of these submarine volcanoes within the context of regional studies were developed by Gautier (1968); Ortí and Sanfeliu (1971); Gómez et al. (1976); Gómez and Goy (1977); Gómez (1979, 1985a, b); Fernández-López et al. (1985); Gómez et al. (2004). The presence of well marked lineaments in the distribution of the volcanic deposits was first published by Gómez (1979), who defined the Caudiel and the Alcublas fault zones (Fig. 3C), and lately corroborated by Ortí and Vaquer (1980). The NW oriented Caudiel Fault Zone is around $150 \mathrm{~km}$ long and was inferred by looking differences in the thickness of the Jurassic stratigraphic units and specially realizing the alignment of volcanic deposits. Other active faults, such as the Alcublas and Teruel faults, also include volcanic outcrops (Fig. 2 and 3 ), but they will not be covered in this paper.
Thickness and facies distribution during Middle Jurassic were mainly controlled by this network of synsedimentary faults, as well as by another set of subordinate and shorter northeast trending faults (Fig. 2). Active faults differentiated unequally subsiding blocks, conforming palaeogeographic highs and adjacent depocentres. For example, the Ateca Fault induced separation of the Aragonese and Castillian platforms and also contributed to the delimitation of depocentres within the El Maestrazgo High.

The regional geological mapping program performed by the Instituto Geologico y Minero de España (IGME) represented a considerable advance in locating outcrops of Jurassic volcanic rocks in different areas, specially along the Caudiel Fault Zone (Gautier, 1974; Abril et al., 1975; Campos et al., 1977; Abril et al., 1978; Adrover et al., 1983).

The first geochemical and petrogenetic data related to the Jurassic volcanism of the Iberian Range were contributed by Ancochea et al. (1988). Additional works mainly oriented to constrain the age of the volcanism were carried out by Lago et al. (1996); Martínez-González et al. (1996); Martínez et al. (1996a, b, c, d, 1997a, b, 1998); Valenzuela et al. (1996) and Lago et al. (2004). However, these works were only able to locate the volcanic deposits into the framework of the lithostratigraphical units, previously defined by Goy et al. (1976) and Gómez and Goy (1979), resulting in a poor stratigraphical resolution because one of the formations, containing many of the volcanic rocks, spans for most of the Middle Jurassic. Very few papers try to specify the age of the volcanism at a more precise resolution on the basis of biostratigraphical criteria (Gómez et al., 1976; Fernández-López, 1985; Fernández-López et al., 1985).

The objective of the present paper is to contribute to understanding the behaviour of a magma-rich passive margin, represented by the Lower-Middle Jurassic volcanism of the Iberian Basin, through the study of the two volcanic phases linked to the Caudiel Fault Zone during the Middle Jurassic. To achieve this goal, the age of these volcanisms will be determined at as high stratigraphic resolution as possible. These volcanics are interbedded within a succession of ammonitebearing carbonate rocks, belonging to the Casinos and El Pedregal formations and deposited in an open marine shallow platform environment (Gómez and Goy, 2005; Gómez and Fernández-López, 2006), which favours the use of ammonite-based biostratigraphical methods.

\section{Materials and methods}

Methods applied to perform the present study are mainly based on field work, which consisted in the geological mapping at a detailed scale (in the order of 1:10,000 to $1: 25,000$ ) of the outcrops of volcanic deposits and surrounding sedimentary rocks, and the study of 9 stratigraphical sections. These allowed the collection of 360 specimens of ammonites, whose taxonomical and taphonomical determination 
Fig.1.- Palaeogeographical map showing the distribution of continental masses and oceans during the Middle Jurassic. Iberia occupied a key position between the African, North American and Euroasiatic plates. At this time, spreading becomes active in the Central Atlantic and the segment of the Ligurian Tethys located southeast of Iberia. The position of the studied area and of the Jurassic volcanic deposits are marked. Modified after Ziegler (1990), Stampfli and Borel (2002, 2004), Stampfli et al. (2002), Stampfli and Hochard (2009), Osete et al. (2011) and Schettino and Turco (2011). Abbreviations: Ab-Alboran. $\mathrm{CSH}-$ Corsica-Sardinia High. EH-Ebro High. FC-Flamish Cap. GB-Grand Bank. hA-High Atlas. LBM-London-Braband Massif. mA-Middle Atlas. MC-Massif Central High. NFB-East Newfoundland Basin. RM-Renish Massif. UM-UmbriaMarché.

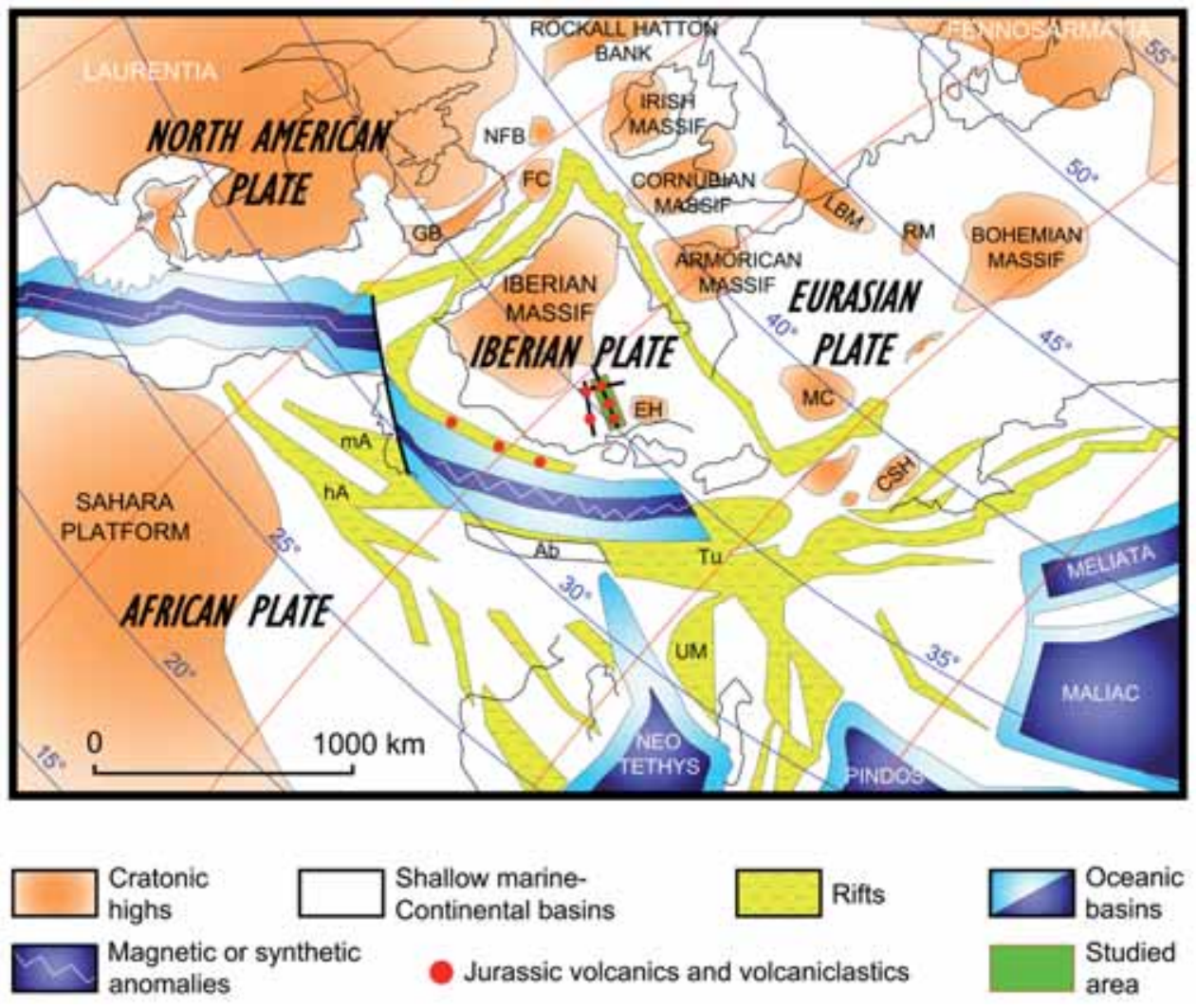

has been carried out by Prof. S. Fernández-López, Prof. S. Ureta and Prof. A. Goy of the Departamento de Paleontología of the Facultad de Ciencias Geológicas of the Universidad Complutense de Madrid. Regarding the taphonomical preservation, the letter (r) is used to identify the specimens that have been accumulated (with no movement) or resedimented (transported, but into the same bed), (w) for the specimens that have been reelaborated (reworked from older beds) and $(\mathrm{r} / \mathrm{w})$ for the specimens in assemblages that contain fossils resedimented and reelaborated. The obtained biostratigraphical units have been referred to the standard chronozones of the Early Jurassic in Europe (Page, 2003) and of the Middle Jurassic in NW European/Subboreal Province (Callomon, 2003), except for: Including Ovalis as subchronozone of Laeviuscula Chronozone (Fernández-López, 1985), using Propinquans instead of Sauzei Chronozone (i.e. FernándezLópez and Mouterde, 1994; Fernández-López, 1997a, b), as well as Niortense instead of Subfurcatum Chronozone (i.e. Fernández-López and Mouterde, 1994; Fernández-López, 1997a, b). Lithostratigraphic units are referred to the previously defined formations (Gómez et al. 2003, Gómez and Fernández-López, 2004a), and the $3^{\text {rd }}$ order sedimentary ciclicity to the shallowing and deepening cycles of the Iberian Range defined by Gómez and Fernández-López (2004b) and Gómez and Goy (2005) (Fig. 4).

\section{Results}

The volcanic deposits studied are located along the Caudiel Fault Zone and have been arranged into three main outcrops
(Figs. 2, 3). From SE to NW, these outcrops have been called Caudiel, Pina-Barracas and Sarrión, respectively. The Caudiel outcrop, placed in its southeastern part, has been studied throughout the CA-1 and CA-31 stratigraphic sections. The Pina-Barracas outcrop, placed in the central part of the Fault Zone, can be divided into three minor outctops: the Pina-Barracas.1 outcrop, where the PI-BA.1-5 and PI-BA.1-7 sections have been described, the Pina-Barracas.2 outcrop, where the PI-BA.2-4 section has been measured, and the Pina-Barracas. 3 outcrop, depicted by the PI-BA.3-1 section. Finally, in the northwest area, the Sarrión outcrop includes three other minor outcrops: the Sarrión.1 outcrop, where the SA.1-1 section was studied, the Sarrión.2 outcrop, represented by the SA.2-1 section, and the Sarrión.3 outcrop, characterized by the SA.3-1 section (Fig.3C). The lithological and bioestratigraphical content of the studied sections are described in the following paragraphs.

\subsection{Volcanic deposits}

The Jurassic volcanism of the Iberian Basin is mainly represented by basaltic rocks that show chemical alkaline affinity (Ancochea et al., 1988; Lago et al., 2004) and manifested by three types of volcanic deposits: 1) massive lava flows, 2) primary volcaniclastic, or pyroclastic, deposits, and 3) secondary volcaniclastic, or epiclastic, deposits.

1) Lava flows are rare and generally represent thin deposits of reduced lateral extension. They are composed of olivine, augite and variable proportions of plagioclase (Ancochea $e t$ al., 1988; Lago et al., 2004). Vesicles up to 3-4 cm in diam- 


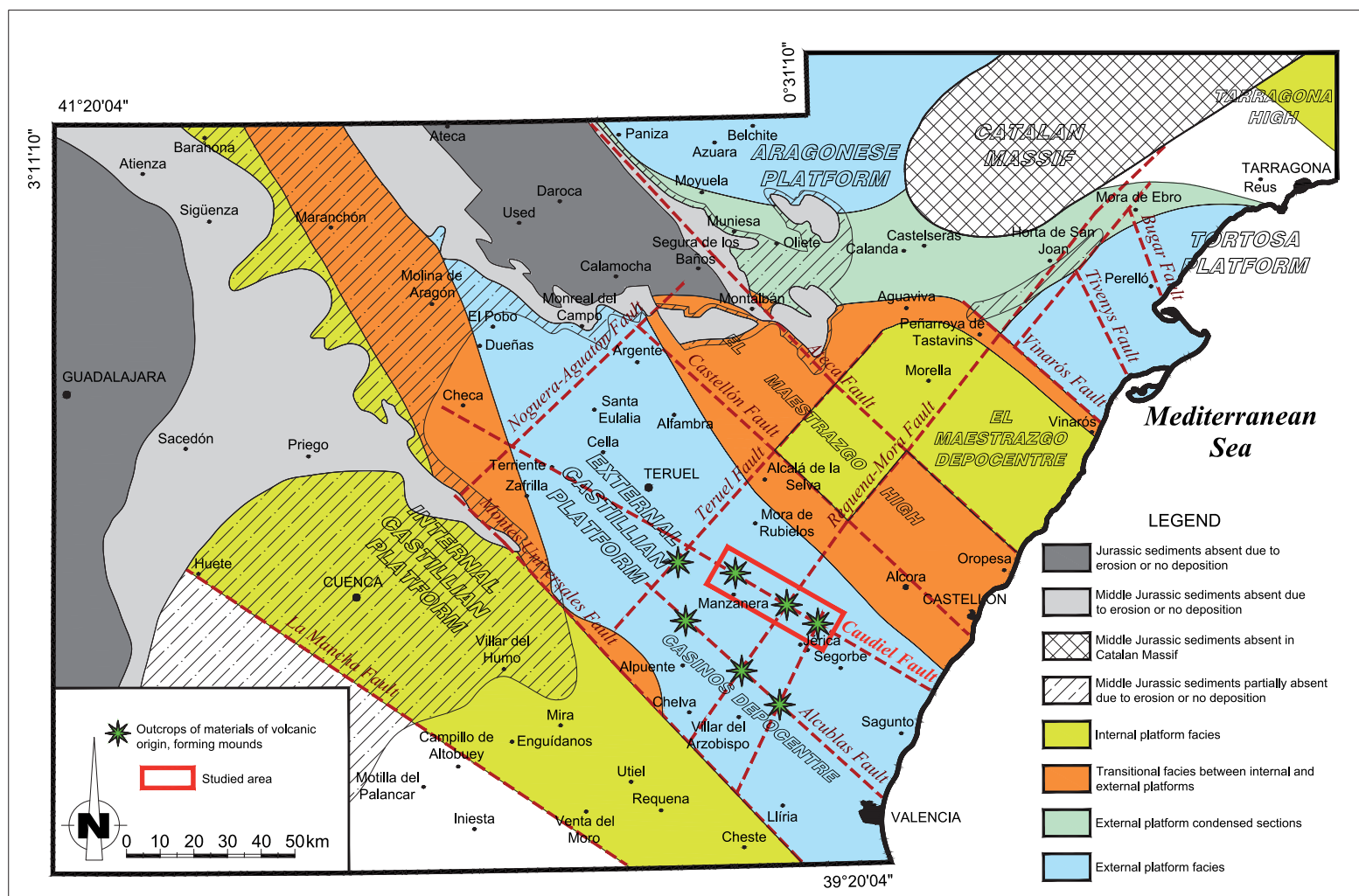

Fig- 2.- Palaeogeographical map of the Iberian Basin showing the reconstruction of the system of platforms developed during Middle Jurassic, as well as the grid of active faults, marked by the presence of volcanic deposits and the distribution of palaeogeographical elements. The age of the volcanic deposits linked to the Caudiel Fault Zone are the main objective of this work. Modified after Gómez and Fernández-López (2006).

a
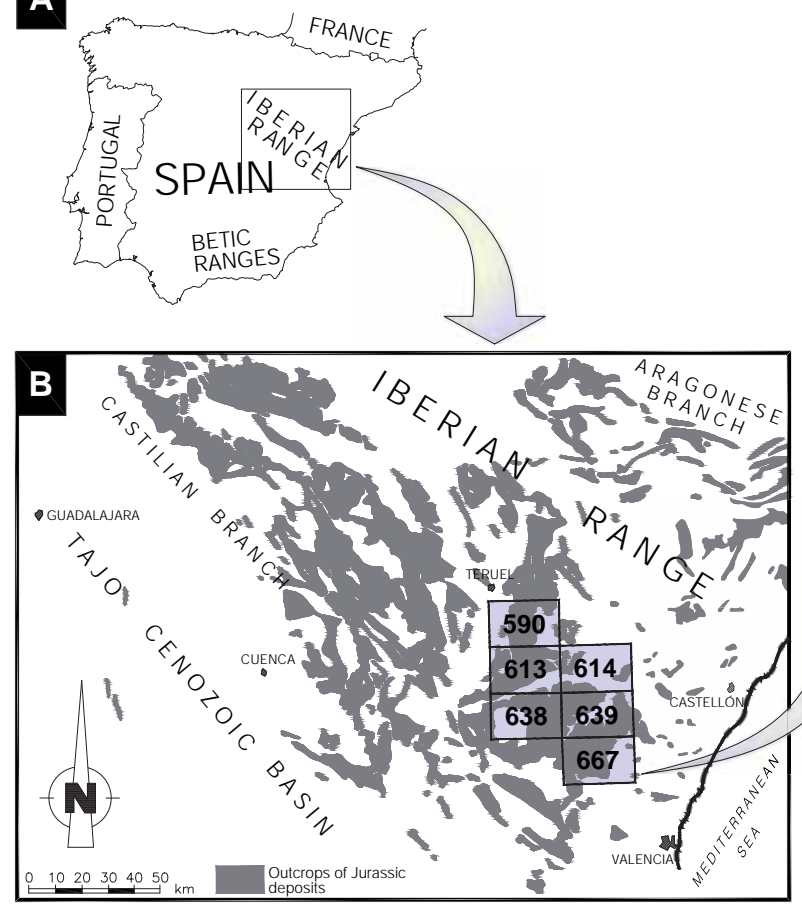

Fig. 3.- A) Location map of the Iberian and the Betic ranges. B) Map showing the outcrops of the Jurassic deposits in the Iberian Range and the location of the sheets of the Geological Map of Spain at the scale of 1:50,000 that contain volcanic deposits of Jurassic age. C) Location of the outcrops of Jurassic volcanic deposits grouped in the main structural lineaments: The NW trending Caudiel and Alcublas Fault Zones and the NE trending Teruel Fault Zone. 
eter, formed from gas bubbles exolved as a result of a low confining hydrostatic and lithostatic pressure, are frequent and, in most cases, filled-up with secondary calcite due to hydrothermal and pore water circulation (Fig. 5A).

A special feature of the lava deposits in the Caudiel outcrop is the presence of fragments of older calcareous sediments which have been exhumed by the ascending lava flows (Fig. 5B), showing the so-called "peperitic texture" (White et al., 2000) (Fig. 5C). In the CA-31 section, the upper part of the lava flows contains reworked peperitized calcareous blocks that come from the underlaying sedimentary walls of the volcanic vents, which have been destroyed or deformed and partially assimilated. Fluidization of the adjacent sediments to the igneous bodies is commonly associated with peperitic processes (Kokelaar, 1982; Waichel et al., 2007). In the studied section, there are evidences of soft deformation, showing the unconsolidated or poorly consolidated stage of the host sediments when the lava flowed through them (Fig. 5D). Paleontological sampling in the carbonate parts of peperitic blocks was unproductive, but the presence of soft deforma- tion in them suggests that the source sediment cannot be much older than the lava flows.

2) Primary volcaniclastic deposits are composed of fragments formed as a direct result of the explosive pyroclastic mechanisms. Disjunction in bowls is a common structure probably due to weathering (Fig. 6A). Juvenile fragments, possibly derived from the magma involved in explosion and cooled before primary accumulation (Fig. 6B), and accidental fragments, expelled by eruptive volcanic processes and coming from the pre-volcanic sedimentary pile (Fig. 6C), are common. According with the Gillespie and Styles (1999) classification, the pyroclastic deposits can range from lapillistone to lapilli-tuff and tuff, but, occasionally, larger lava clasts (bombs of centimetric to decimetric size) are included in the pyroclastic masses, near small and discontinuous lava flows (Fig. 6D).

3) Primary pyroclastic deposits that have been modeled by agents of the sedimentary environment (i.e., currents, waves, tides) at any time after their primary accumulation are considered as secondary volcaniclastic, or epiclastic, deposits

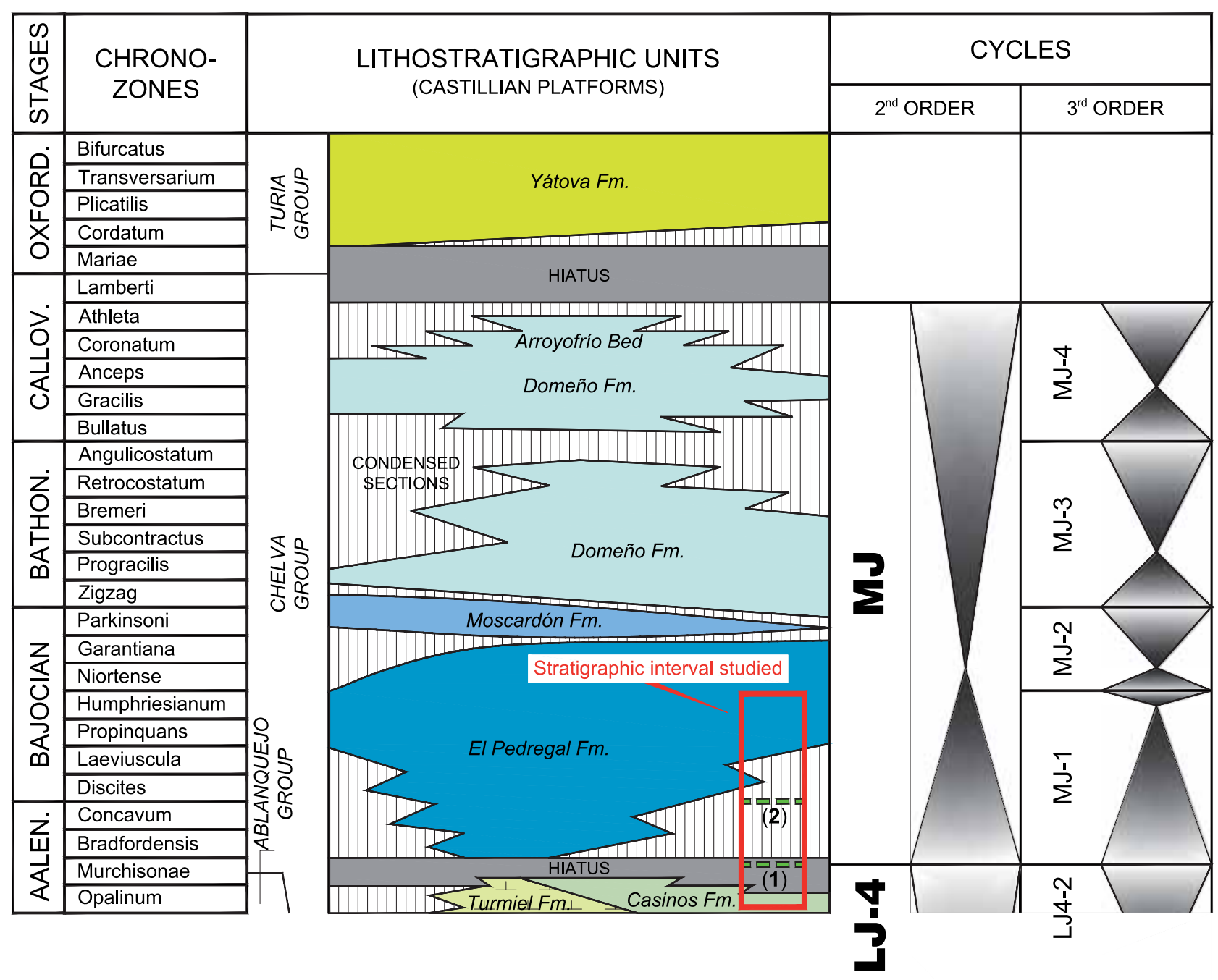

Fig. 4.- Stratigraphic chart showing the lithostratigraphic units of the Middle Jurassic in the Iberian Basin and the deepening and shallowing upward cycles (modified after Gómez y Fernández-López, 2006), as well as the studied stratigraphic interval. (1).- Stratigraphic position of the lower volcanic level (Aalenian). (2).- Stratigraphic position of the upper volcanic level (Upper Aalenian-Lower Bajocian). 

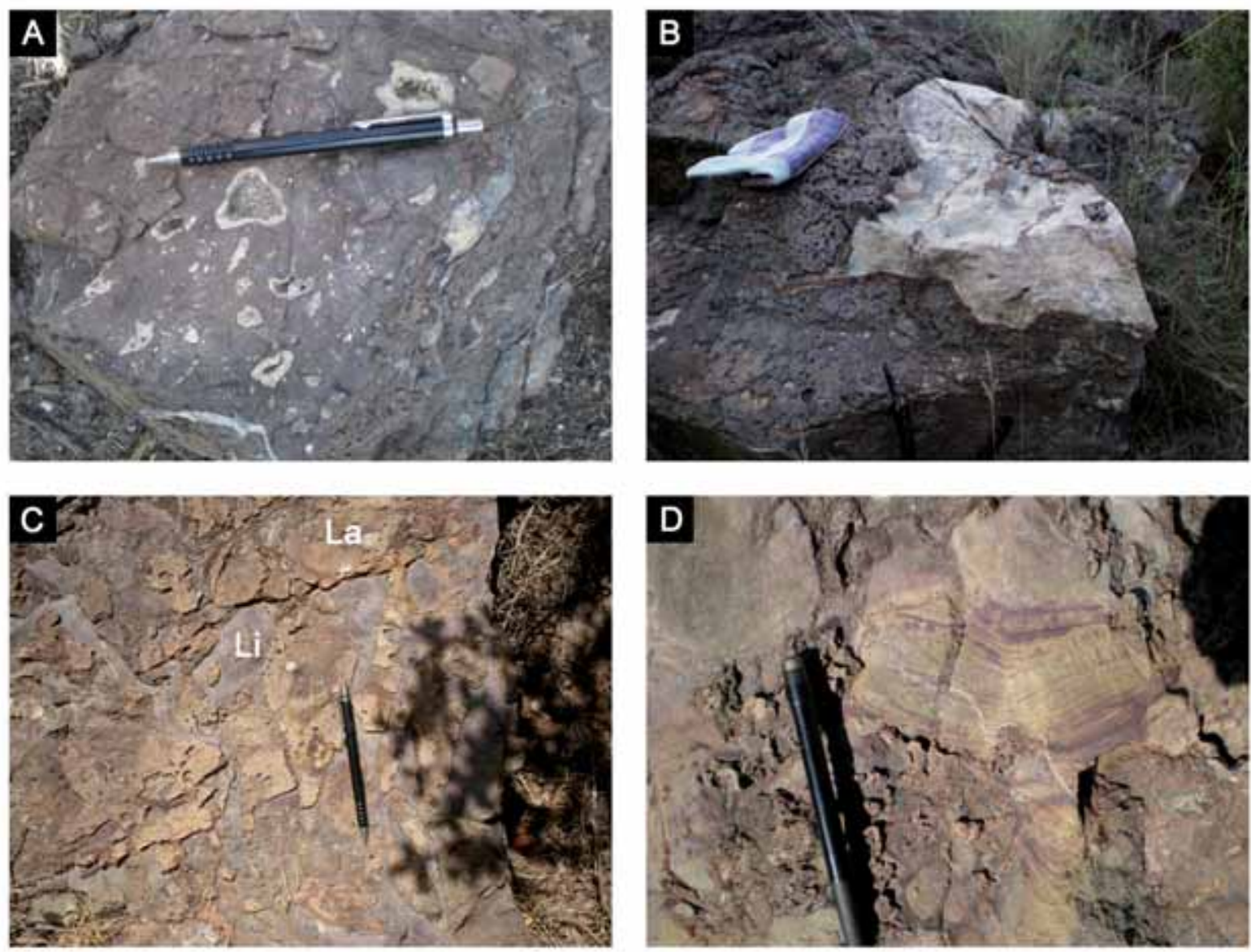

Fig. 5.- Aspects of the lavic rocks in the Caudiel outcrop (level 13 of the CA-31 section). A) Amygdules up to 3-4 cm in diameter filled with secondary calcite. B) Exhumated blocks of limestone partially assimilated by the lava flows. Folded glove as scale is $10 \mathrm{~cm}$ long. C) Interaction between lava flow and wet sediments providing a peperitic texture (La: Lava, Li: Limestone). D) Soft deformation of unconsolidated sediments in peperite. Pen for scale is $14 \mathrm{~cm}$ long.

(Cas and Wright, 1987). This type of deposits, ranging from reworked primary pyroclastic accumulations with simple Xbedding to epiclastic arenites (Fig. 6E) and epiclastic lutites (Fig. 6F), are present in the studied sections.

\subsection{Caudiel outcrop (CA-31 and CA-1 sections)}

The lower part of the CA-31 section (Fig. 7A) is composed of wackestone-packstone bioclastic and intraclastic limestone beds, showing at their tops well developed firmgrounds and hardgrounds with signs of bioturbation (Thalassinoides), early cementation and ferruginous crusts. Remains of echinoids, bivalves, brachiopods, belemnites and ammonites are common. Among the ammonites, the presence of Eudmetoceras sp. (r), Rhodaniceras sp. (r), Ludwigella sp. (r), Graphoceras sp. (r) and Ambersites? sp. (w) characterizes the Concavum Chronozone of the Late Aalenian.

Overlaying the Aalenian limestones, 12 meters of massive lava flows, which extend laterally for at least $500 \mathrm{~m}$ in a north-south direction, can be observed. Calcareous peperitized blocks, coming from pre-volcanic unconsolidated strata, are included in their upper part (Fig. 5B, C and D). The lava flows pass laterally and upwards to volcaniclastic (pyroclastic lapil- listones to tuffs) deposits that include clasts of vesicular lava and of sedimentary carbonates. Maximum thickness of the volcanic deposits in this outcrop is 44 meters.

Levels 16 to 20 are constituted by bioclastic wackestonepackstone limestones thinning upward, containing echinoids, bivalves and microfilaments. The tops show hardgrounds with bioturbation (mainly Thalassinoides) and ferruginous crusts. The upper part (levels 18 to 20) contains Elatmites sp. (r) and Macrocephalites sp. $(\mathrm{r} / \mathrm{w})$ that characterize the Callovian Stage. In the lower part (levels 16 and 17) no ammonites were found, but, based on regional data, these beds can be attributed to the Domeño Formation, defined by Gómez and Fernandez-López (2004a), and probably of Bathonian age.

The uppermost part (level 21) is composed of wackestonepackstone limestones with ferruginous oolites, belonging to the Arroyofrio Bed (defined by Gómez and Goy, 1979), and the top (level 22) is constituted by wackestone-packstone limestones with abundant sponges, typical of the Yátova Formation, Oxfordian in age.

In the CA-1 section (Fig. 7B), located about $2 \mathrm{~km}$ north of section CA-31, the volcanic deposits, here epiclastic, are still present, but they are very thin. Carbonates situated below the epiclastic deposits (8 to 13 in Fig. 7B) are reddish bioclastic 

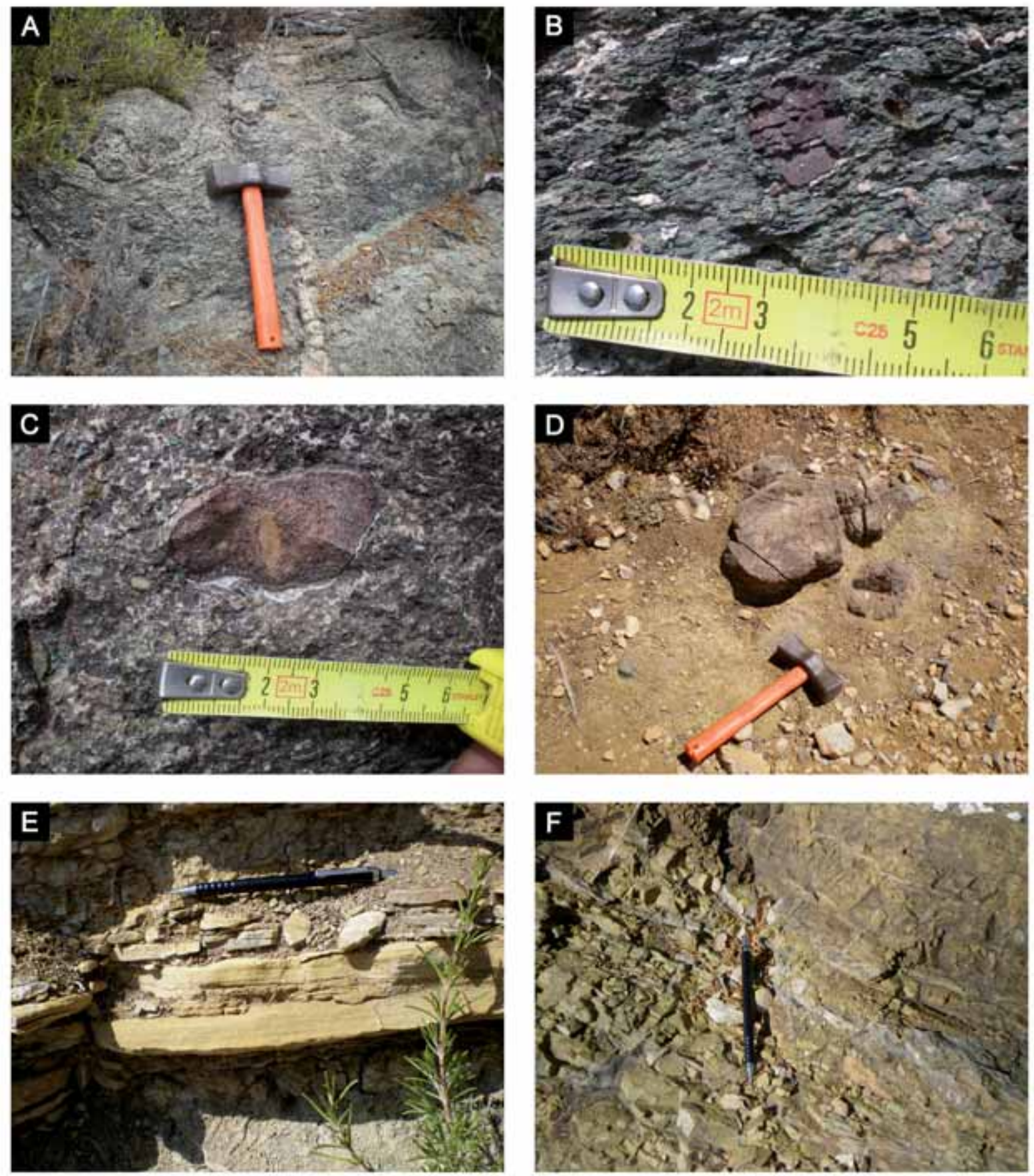

Fig. 6.- Photographs of pyroclastic and epiclastic deposits. A) Primary pyroclastic deposits showing incipient bowls disjunction in the Caudiel outcrop (level 15 of the CA-31 section). B) Basaltic clast included in pyroclastic tuffs (level 15 of the CA-31 section). C) Exhumed clast of sedimentary origin composed of carbonates with ferruginous oolithes. This clast probably comes from the pre-volcanic basal part of the El Pedregal Formation, Concavum Chronozone (level 15 of the CA-31 section). D) Large basaltic bombs included in pyroclastic, lapillistone to lapilli-tuff, deposits (Sarrión.2 outcrop, section not included in this work). E) Epiclastic arenites with internal tractive plano-parallel lamination in Pina-Barracas.1 outcrop (level 2 of the PI-BA.1-7 section). F) Epiclastic lutites in the Pina-Barracas.3 outcrop (level 22 of the PI-BA.3-1 section). Hammer and pen, for scale, have a length of 27 and 14 cm respectively.

wackestone-packstone limestones with disperse ferruginous oolites. Each bed shows bioturbation (Thalassinoides), well developed hardgrounds and ferruginous crusts. In levels 8 and 9, Graphoceras sp. (r/w), Ludwigella sp. (r/w) (Fig. 14A) and Abbasites sp. (w), characterizing the Concavum Chronozone of the Late Aalenian, were found.
Overlaying the $60 \mathrm{~cm}$ thick volcanic deposits, there is a $50 \mathrm{~cm}$ bed of bioclastic wackestone-packstone limestone with crinoids, bivalves, brachiopods and ammonites. Among the ammonites, Haplopleuroceras mundum BUCKMAN (r), Eudmetoceras sp. (w) and Fontannesia sp. (w) indicate an Early Bajocian age, but also a latest Aalenian age is possi- 


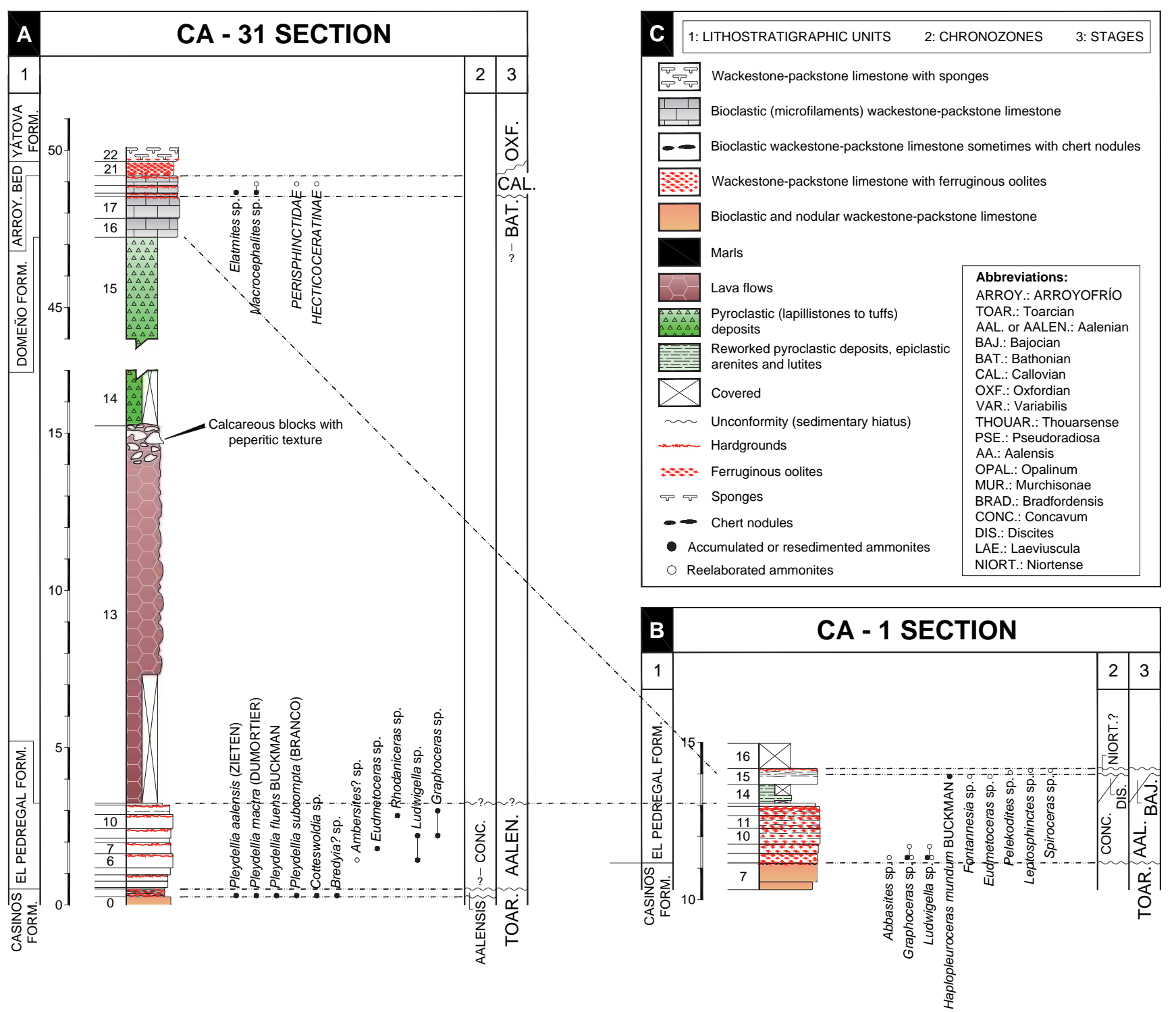

Fig. 7.- A) Stratigraphic column of the CA-31 section in the Caudiel outcrop. B) Stratigraphic column of the CA-1 section. C) Legend of the figures 7 to 12. For the assessment of the taphonomical preservation of the ammonites, the criteria enounced by Fernández-López (1984a, b) have been followed. Notice the correlation of the volcanic deposits between the two sections.

ble. The uppermost $10 \mathrm{~cm}$ show signals of reworking, with several erosive surfaces and ferruginous crusts, and contain Leptosphinctes sp. (w) and Spiroceras sp. (w) of the Late Bajocian. The top of the bed shows a hardground with ferruginous crusts.

\subsection{Pina-Barracas.1 outcrop (PI-BA.1-5 and PI-BA.1-7 sections)}

The lowermost part of Section PI-BA.1-5 (Fig. 8A) is composed of reddish bioclastic wackestone-packstone limestones with ferruginous oolites (beds 9 to 11), containing Apedogyr$i a$ sp. (r) and Brasilia sp. (r) that characterize the Bradfordensis Chronozone of the Aalenian. The $3 \mathrm{~m}$ located above are composed of wackestone-packstone limestones in beds of centimetric thickness, some of which show hardgrounds at their top (12 to 19 in Fig. 8A). Graphoceras sp. (r), Ludwigella sp. (r/w) and Euaptetoceras sp. (r), characterizing the Concavum Chronozone of the Late Aalenian, were collected in these beds. Above, the $2.3 \mathrm{~m}$ of wackestone-packstone limestones (Fig. 13F and G) with chert nodules (20 to 23 in Fig. 8A) provided scarce ammonite specimens of Haplopleuroceras subspinatum BUCKMAN (r) and Haplopleuroceras mundum BUCKMAN (r) that could indicate a late Concavum (Late Aalenian) to early Discites (Early Bajocian) chronozones.

Overlaying these limestones, there is a $4.5 \mathrm{~m}$ thick volcaniclastic succession (pyroclastic, lapillistones to tuffs), 


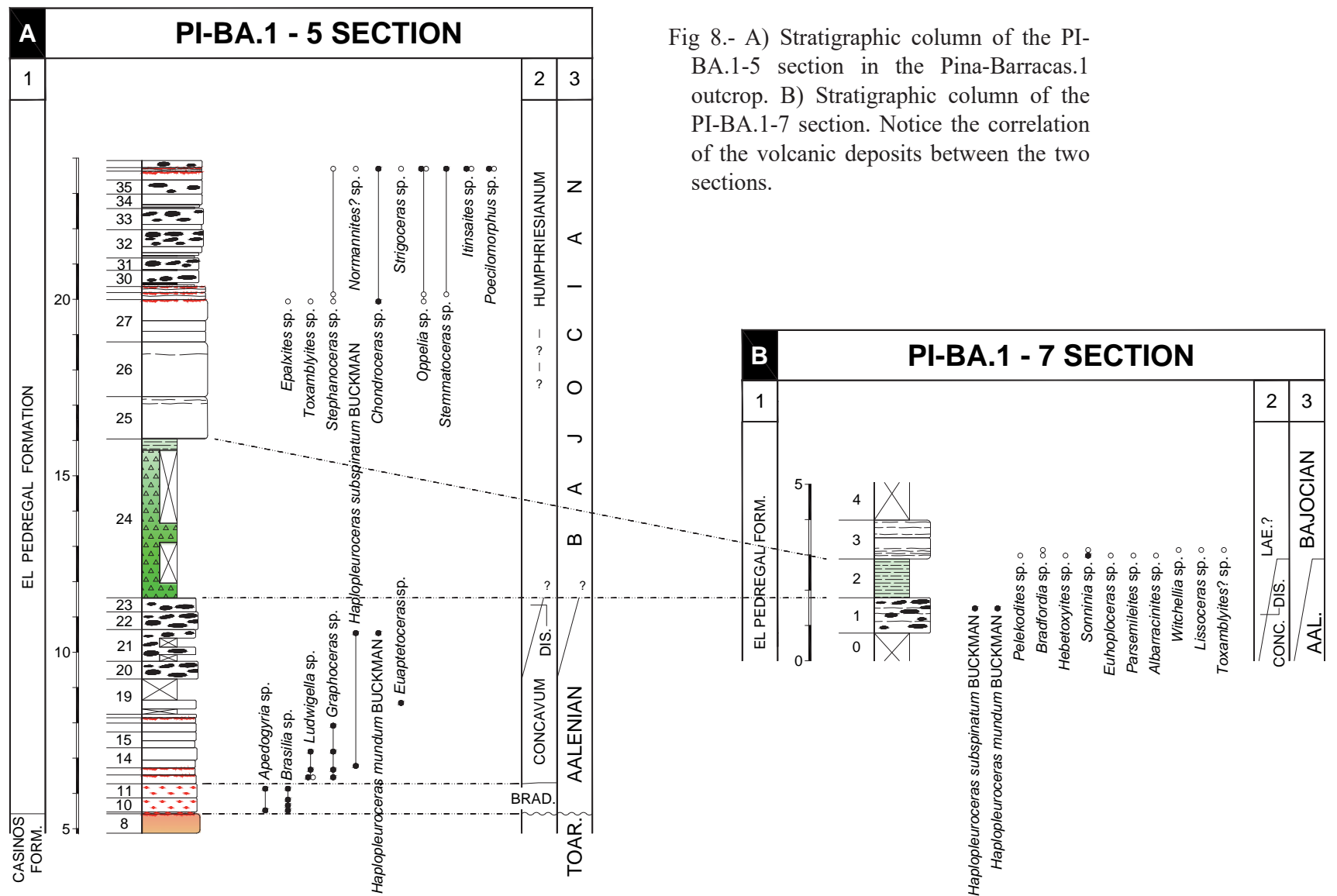

where fragments of lava flows and of sedimentary carbonate rocks can be observed. Reworked epiclastic deposits also were accumulated at the top of the stratigraphic section. The volcaniclastic deposits are covered by $4.3 \mathrm{~m}$ of bioclastic wackestone-packstone limestones in thick beds, mainly constituted by fragments of crinoids and bivalves commonly concentrated in rills (Fig. $13 \mathrm{H}$ and I). In the upper part, the beds are thinner and include hardgrounds at their tops. Despite that no solid evidence was obtained, levels 25 and 26 could belong to the Propinquans Chronozone of the Early Bajocian. In the upper part of level 27, Chondroceras sp. (r), Stephanoceras sp. (w), Epalxites sp. (w), Toxamblyites sp. (w), Oppelia sp. (w) and Stemmatoceras sp. (w) constitute an assemblage that probably belongs to the Humphriesianum Chronozone of the upper part of the Early Bajocian.

The uppermost part of the PI-BA.1-5 section is composed of $3.4 \mathrm{~m}$ of wackestone-packstone limestones with chert nodules, and interbedded thin marls in the lower part. Below a hardground, marking the top of the succession, the presence of Chondroceras sp. (r), Stemmatoceras sp. (r), Oppelia sp. (r/w), Itinsaites sp. (r/w), Poecilomorphus sp. (r/w) (Fig. 14 D), Stephanoceras sp. (w), Strigoceras sp. (r) and Normannites? sp. (w) continues characterizing the Humphriesianum Chronozone of the upper part of the Early Bajocian.

In the PI-BA.1-7 section (Fig. 8B), the $1 \mathrm{~m}$ thick arenite and lutite epiclastic deposits represent the pinching out of the volcanics described in the PI-BA.1-5 section. In the limestones located below the epiclastic rocks, Haplopleuroceras subspinatum BUCKMAN (r) and Haplopleuroceras mundum BUCKMAN (r), which could indicate the top of the Concavum Chronozone of the Late Aalenian or the lowermost part of the Discites Chronozone of the Early Bajocian, have been found. The limestones overlaying the volcanic deposits contain Sonninia sp. (r/w), Pelekodites sp. (w), Bradfordia sp. (w), Hebetoxyites sp. (w), Euhoploceras sp. (w), Parsemileites sp. (w), Albarracinites sp. (w), Witchellia sp. (w), Lissoceras sp. (w) and Toxamblyites? sp. (w). This ammonite assemblage, concentrated in a $20 \mathrm{~cm}$ thick interval, is composed of resedimented and mainly reworked fossils, but with a time amplitude of more than a chronozone. The rock body that includes this assemblage could form in the Laeviuscula Chronozone (Early Bajocian), although it could also be younger.

\subsection{Pina-Barracas.2 outcrop (PI-BA.2-4 section)}

Overlaying the carbonates of the Upper Toarcian (Variablilis Chronozone) and Aalenian (Murchisonae Chronozone), belonging to the Casinos Formation (Fig.13A, B, C, D and E), a $0.4 \mathrm{~m}$ thick layer of bioclastic wackestone-packstone limestones with ferruginous oolites (level 44) represent the base of the El Pedregal Formation. The upper part of this bed 


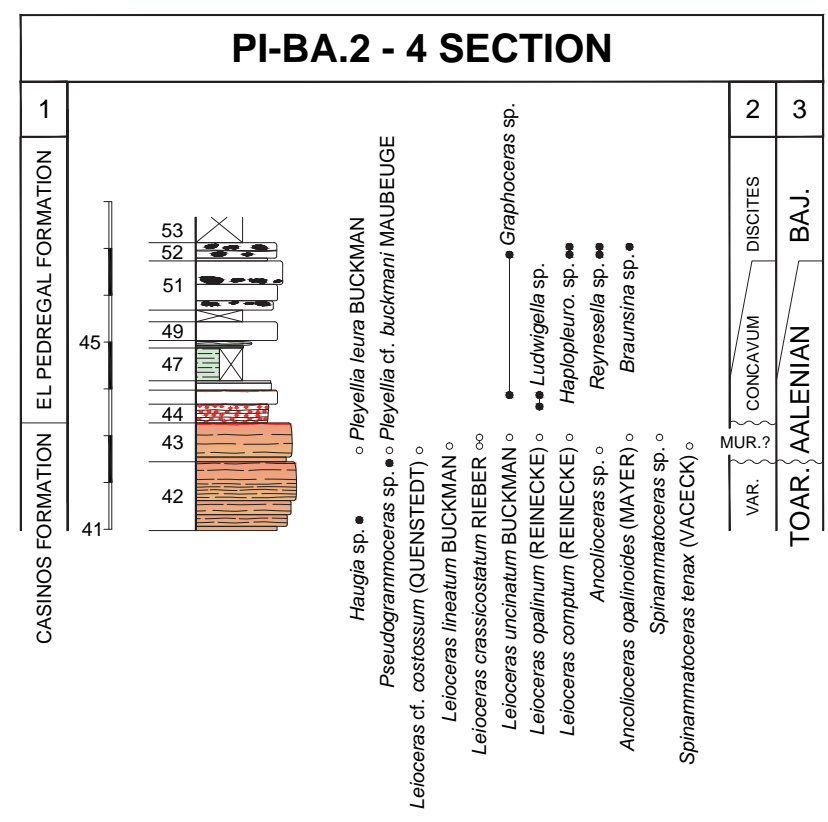

Fig. 9.- Stratigraphic column of the PI-BA.2-4 section in the Pina-Barracas. 2 outcrop.

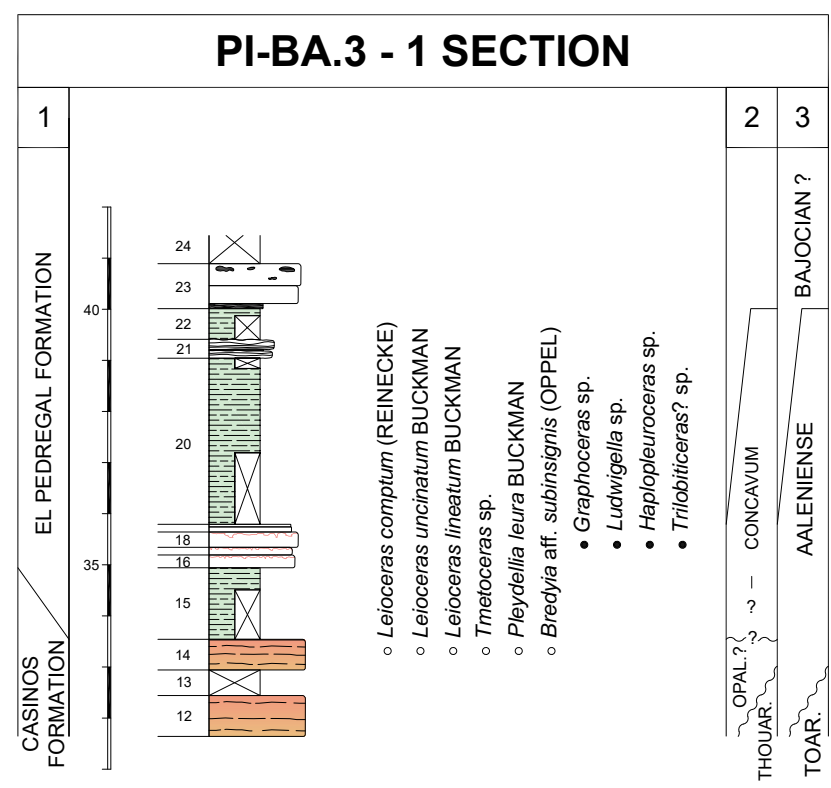

Fig. 10.- Stratigraphic column of the PI-BA.3-1 section in the PinaBarracas. 3 outcrop.

contains Ludwigella sp. (r) (Fig. 14B). Above the ferruginous oolites, there are thinly bedded bioclastic wackestone-packstone limestones with hardgrounds at their top, in which Graphoceras sp. (r) and Ludwigella sp. (r) of the Late Aalenian Concavum Chronozone have been collected. The Aalenian carbonates are overlain by $0.9 \mathrm{~m}$ of volcano-sedimentary arenite and lutite epiclastic deposits (47 in Fig. 9). The limestones located above the epiclastic deposits contain Graphoceras sp. (r), Haplopleuroceras sp. (r), Reynesella sp. (r) and Braunsina sp. (r). This is an assemblage that identifies with no doubts the lowermost part of the Discites Chronozone of the Early Bajocian.

\subsection{Pina-Barracas.3 outcrop (PI-BA.3-1 section)}

The bioclastic wackestone-packstone limestones of the level 14 in the PI-BA.3-1 section (Fig. 10) identified as belonging to the Casinos Formation. In its middle part, a continuous horizon has provided Leioceras comptum (REINECKE) (w), Leioceras uncinatum BUCKMAN (w), Leioceras lineatum BUCKMAN (w), Tmetoceras sp. (w), Pleydellia leura BUCKMAN (w) and Bredyia aff. subinsignis (OPPEL) (w). This is an assemblage with mixed chronorecords of the Aalensis (Late Toarcian) and Opalinum (Early Aalenian) chronozones, where all specimens are reelaborated. The rock body could have been deposited during the Opalinum Chronozone, but it could also be younger. Almost 2 metres of volcaniclastic (epiclastic) deposits lie above level 14 (the lowermost volcanics, corresponding to the level 15). On top of that, a new interval of bioclastic wackestone-packstone limestones (beds 16 to 19) can be observed. Hardgrounds, with bioturbation (mainly Thalassinoides) and ferruginous crusts, are present at the top of the beds. In level 18, the presence of Graphoceras sp. (r), Ludwigella sp. (r), Haplopleuroceras sp. (r) and Trilobiticeras? sp. (r) characterizes the Concavum Chronozone. Above this sedimentary interval lies the about $4 \mathrm{~m}$ thick uppermost volcanic accumulation (levels 20 to 22), entirely composed of epiclastic arenites (level 21) and lutites (Fig. $6 \mathrm{~F}$ ). The section ends with bioclastic wackestone-packstone limestones with chert nodules, which, based on regional data, have a probable Bajocian age.

\subsection{Sarrión.1 and Sarrión.2 outcrops (SA.1-1 and SA.2-1 sections)}

In the SA.1-1 section (Fig. 11A), above the carbonates of the Upper Toarcian Casinos Formation, the bioclastic wackestone-packstone limestones of the El Pedregal Formation (beds 4 to 9 in Fig. 11A) contain Brasilia sp. (r), Apedogyria sp. (r/w), Abbasites sp. (r) and Abassitoides sp. (r), characterizing the Bradfordensis Chronozone of the Aalenian. Above, the bioclastic wackestone-packstone limestones with chert nodules (interval 10-12) include Graphoceras sp. (w) and Ludwigella sp. (w) in the lower part, and Ludwigella sp. (r) and Haplopleuroceras subspinatum BUCKMAN (r) (Fig. 14C) in the upper part. This interval represents the Concavum Chronozone of the Late Aalenian. In the bioclastic wackestone-packstone limestones with chert nodules of the interval 14-15, Haplopleuroceras subspinatum BUCKMAN. (r), Haplopleuroceras cf. mundum BUCKMAN (r), Haplopleuroceras crassum GERARD (r), Westermannites sp. (r) and Euhoploceras sp. (r) were obtained, indicating the presence of the Discites Chronozone of the Early Bajocian. Overlaying the limestones with chert nodules, there are 12.5 $\mathrm{m}$ of massive lava flows, locally partly covered. They are fol- 


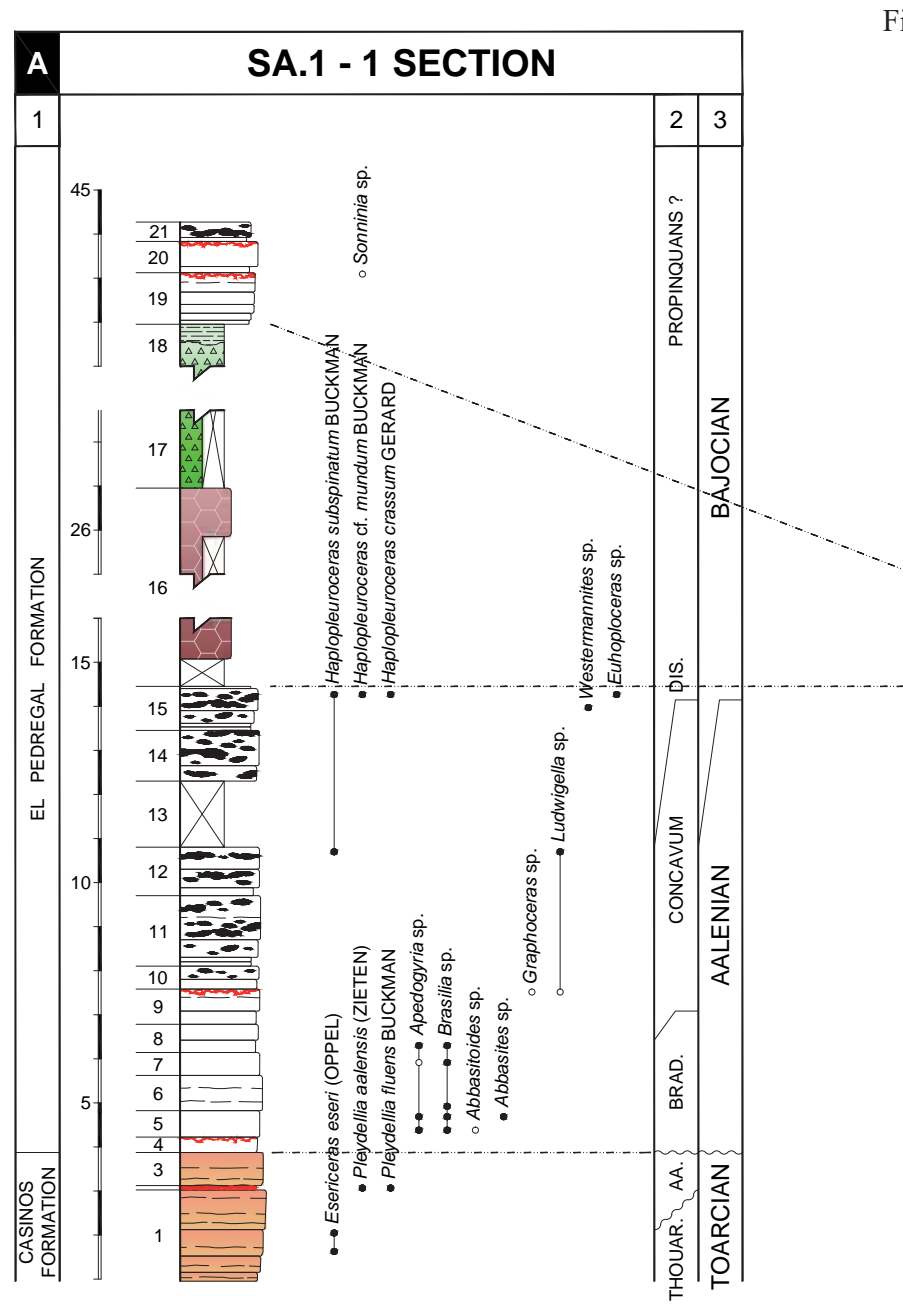

lowed by $15 \mathrm{~m}$ of volcaniclastic (pyroclastic, lapillistones to tuffs, and epiclastic) deposits that include clasts of lavas and of sedimentary carbonates. The section ends with bioclastic wackestone-packstone limestones with chert nodules (19-21 in Fig. 11A), forming shallowing upward sequences crowned by hardgrounds. Level 19 has provided Sonninia sp. (w) that, even not resolute, could identify the Propinquans Chronozone of the Early Bajocian.

The Section SA.2-1 shows the pinching out of the volcanic deposits in the Sarrion.2 outcrop, where the epiclastic deposits are only $1.5 \mathrm{~m}$ thick (Fig. 11B). The base of the section, immediately under the volcanics, is represented by bioclastic wackestone-packstone limestones with chert nodules, similar to the facies located below the volcanic deposits in section SA.1-1. The volcaniclastics are bounded by bioclastic wackestone-packstone limestones organized in shallowing upward sequences, which are topped with hardgrounds. Underneath the hardground of the second sequence (interval 3), specimens of Braunsina sp. (r) have been found, pinpointing the Discites Chronozone of the Early Bajocian. The taxorecords of the upper part of interval 3 (Fig. 11B) show an assemblage of reworked ammonites clearly younger than the Discites Chronozone, probably corresponding to the Laeviuscula Chronozone.
Fig. 11-. A) Stratigraphic column of the SA.1-1 section in the Sarrion.1 outcrop. B) Stratigraphic column of the SA.2-1 section in the Sarrion.2 outcrop. Notice the correlation of the volcanic deposits between the two sections.

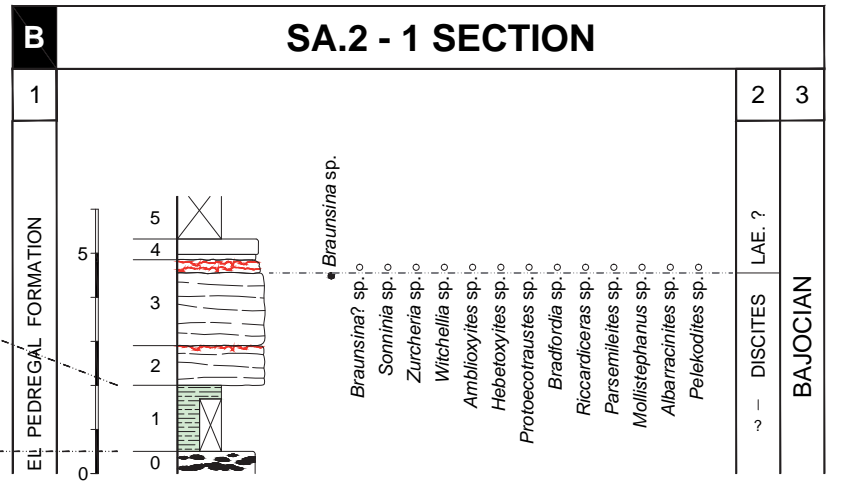

\subsection{Sarrión.3 outcrop (SA.3-1 section)}

In the Sarrión.3 outcrop (Fig. 12), no deposits corresponding to the Concavum Chronozone have been found. The limestones of the Bradfordensis Chronozone (interval 7 to 10), with Brasilia sp. (r) and Apedogyria sp. (r), overlay the limestones of the Upper Toarcian and underlay the volcanics. Above the volcaniclastic (epiclastic) deposits, the limestones of the interval 13 to 15 contain Sonninia sp.(r), indicating the possibility that they were deposited during the Early Bajocian.

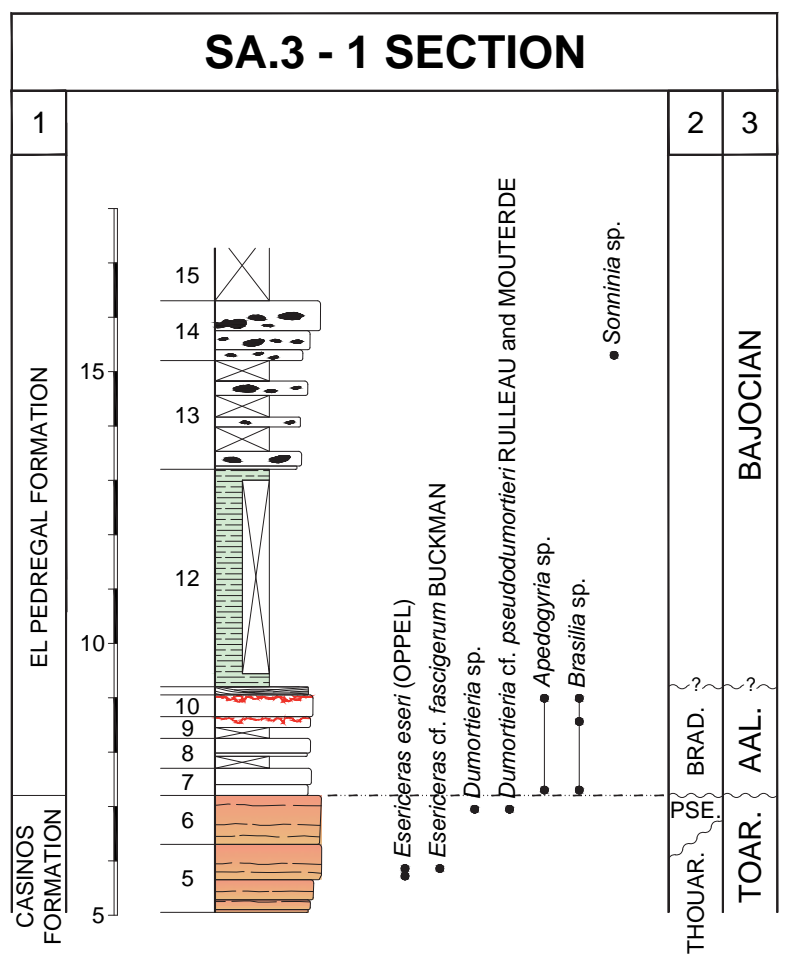

Fig. 12.- Stratigraphic column of the SA.3-1 section in the Sarrion.3 outcrop. 

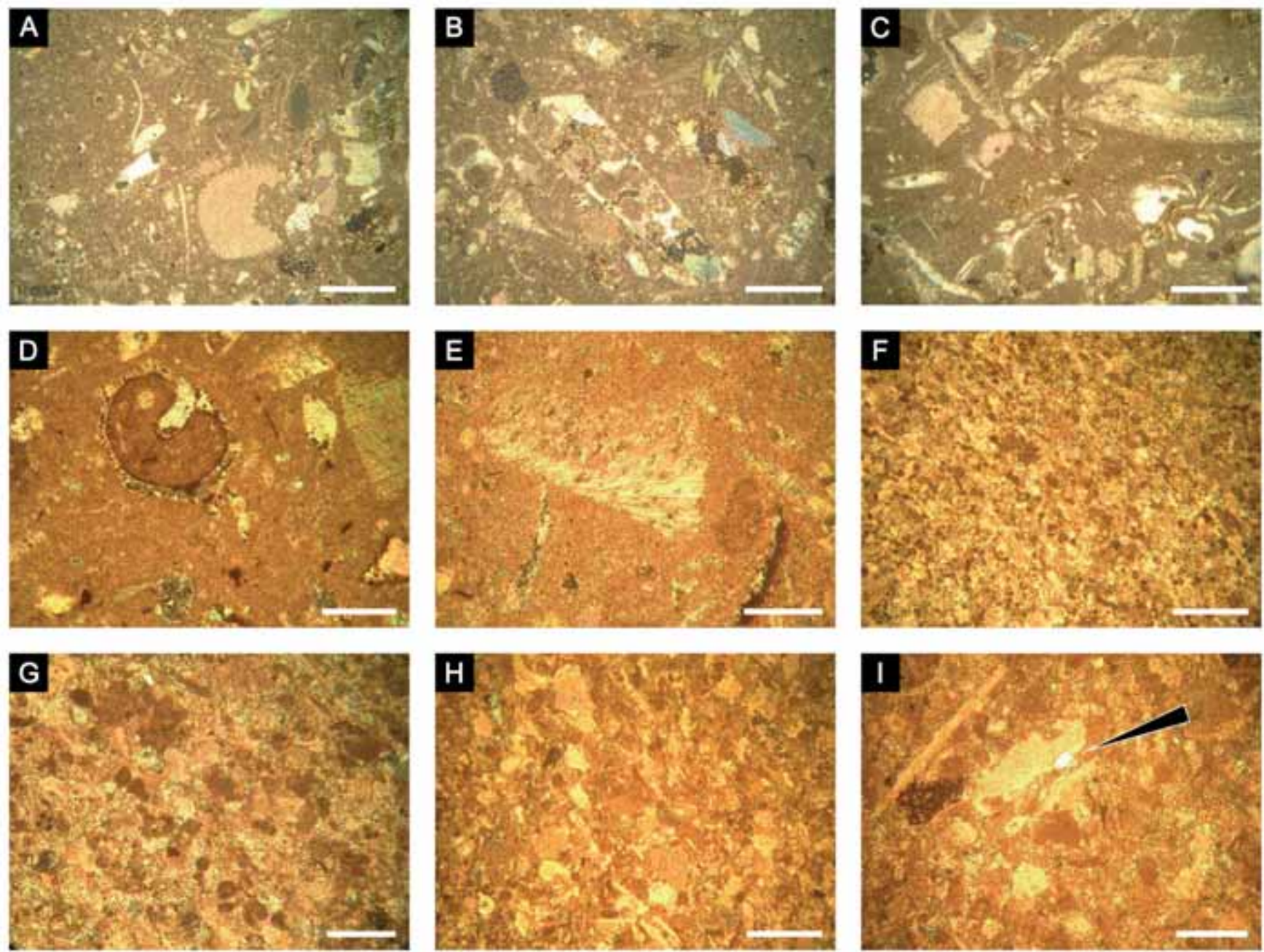

Fig. 13.- Photomicrographs of the carbonates located below and above the volcanic deposits. A) to E) Samples from level 42 of the PI-BA.2-4 section belonging to the Casinos Formation. Poorly sorted bioclastic wackestones with disarticulated plates of echinoderms and fragments of thick-shelled bivalves, gastropods, brachiopods, foraminifera and punctuated brachiopods (E). The samples show a mud-supported fabric where skeletal grains are embedded into a micritic to microsparitic matrix. Originally calcitic bioclasts are well preserved, but the aragonitic shells were dissolved and the moulds were later filled with sparry calcite. Longitudinal (B) and transverse (D) sections through gastropods show neomorphic alteration. Characteristic single-crystal extinction in large echinoderm fragments is common. Scale bars in A), B) and C) are 500 $\mu \mathrm{m}$. Scale bars in D) and E), $200 \mu \mathrm{m}$. Photomicrographs F) and G) from level 23 of the PI-BA.1-5 section, belonging to the El Pedregal Formation located immediately below the volcanic deposits. Fine-grained, well-sorted bioclastic and peloidal packstone, showing a grain-supported fabric with scarce patches of micritic matrix. Allochems are packed, and intergranular cementation, with small but approximately equal size spar crystals, can be observed. Bioclastic grains are mainly of echinoids (plates of crinoids) and less abundant fragmented thin-shelled bivalves. Scale bar in F) corresponds to $500 \mu \mathrm{m}$. Scale bar in G), to $200 \mu \mathrm{m}$. Samples H) and I) were obtained from level 31 of the PI-BA.1-5 section, which belongs to the El Pedregal Formation and locates above the volcanic deposits. Well-sorted, fine-grained bioclastic, peloidal and intraclastic packstone. Micrite has been recrystallized to microspar and only small patches of original micrite are still visible. Bioclasts are almost exclusively echinoderms and fragmented thin-shelled bivalves (microfilaments). Echinoderm plates are surrounded by calcitic overgrowths that formed in optical continuity with them (syntaxial rims). Silt-sized detrital quartz (subhedral or anhedral) grains (black arrow), exhibiting undulose extinction, represents less than 1\%. Scale bar in H) $500 \mu \mathrm{m}$. Scale bar in I) $200 \mu \mathrm{m}$. Cross-polarized light in all the microphotographs.

\section{Discussion}

As mentioned above, the uppermost Triassic and LowerMiddle Jurassic deposits were sedimented under a post-rift stage (Salas and Casas, 1993; Salas et al., 2001; SánchezMoya and Sopeña, 2004). However, it is worth to distinguish between the magma-poor uppermost Triassic and most of the Lower Jurassic deposits, and the magma-rich sequences deposited between the Pliensbachian and the Bajocian. As mentioned by Franke (2013) and Geoffroy et al. (2015), these volcanisms, characterizing the magma-rich passive margins, are associated with extrusion of predominantly mafic magmas, commonly related to mantle plumes and Large Igneous Provinces.

\subsection{Marine environment of the volcanic emissions}

Volcanic deposits interbedded within sediments containing marine fossils, like the deposits cropping out along the Caudiel Fault Zone, have widely been interpreted as accu- 

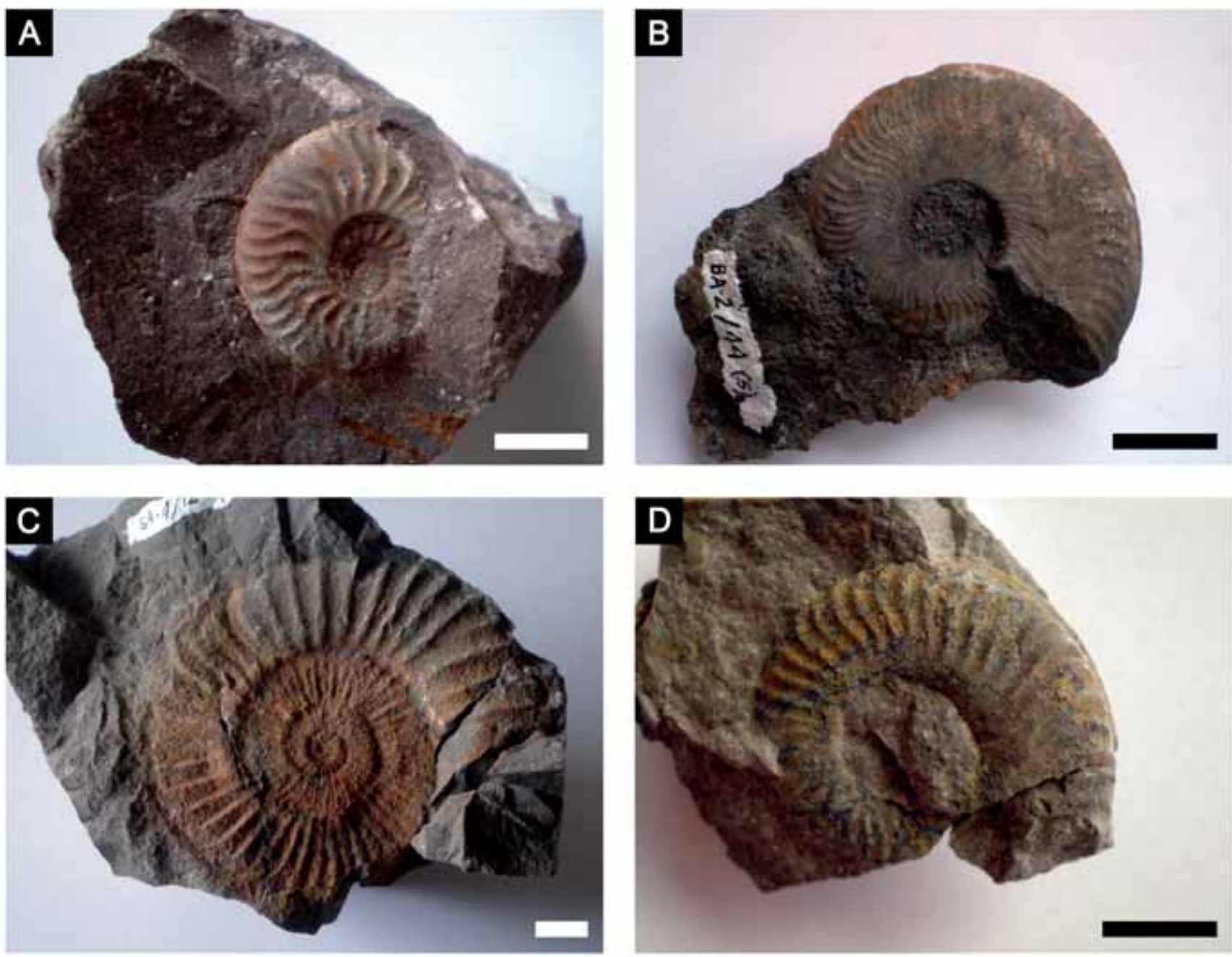

Fig. 14.- Ammonites of the Aalenian and Bajocian. A) Ludwigella sp. [microconch] (resedimented) of the Aalenian Concavum Chronozone, from level 8 of the CA-1 section. B) Ludwigella sp. [microconch] (resedimented) of the Aalenian Concavum Chronozone, from the level 44 of the PI-BA.2-4 section. C) Haplopleuroceras subspinatum BUCKMAN (resedimented) of the Aalenian Concavum Chronozone, from the level 12 of the SA.1-1 section. D) Poecilomorphus sp. (resedimented) of the Humphriesianum Chronozone of the Bajocian, from level 37 of the PI-BA.1-5 section. Taxonomical and taphonomical determinations of A), B) and D) were carried out by Professor Sixto Fernández-López (Departamento de Paleontología, U.C.M.). Determination of C), by Professor Soledad Ureta (Departamento de Paleontología, U.C.M.).

mulated in a marine depositional environment (i.e. White and McPhie, 1997; Allen and McPhie, 2000; Raos and McPhie, 2003; Valenzuela et al., 2011; Soriano et al., 2012). Additional evidence is the presence, within the epiclastic accumulations, of marine fossils derived either from the colonization by benthic communities or as a result of death, fall and burial of nektonic organisms. That is the case in a zone of the Sarrión. 2 outcrop (located about $1.5 \mathrm{~km} \mathrm{NE}$ of the SA.21 section), where a thick primary pyroclastic accumulation is overlain by several meters of reworked epiclastic material showing X-bed structures (Fig. 15A and B). Within the Xbedded epiclastic mass, an exceptional specimen of ammonites, represented by an internal mould filled with epiclastic volcano-sedimentary deposits, has been collected (Fig. 15C). The process of fossilization required the previous existence of volcanic piles in the submarine floor.

\subsection{Influence of the volcanic mounds in the carbonate facies}

Volcanic accumulations that made up mounds strongly affected the facies distribution around them in some localities. The normal facies at the scale of the External Castillian Platform (Fig. 3) is the wackestone to packstone limestones mainly formed by fragments of microfilaments, sections of a thinshelled pelagic bivalve (Bositra). However, in the vicinities of the Caudiel mound, this facies is substituted by packstone to grainstone, high-energy facies of crinoids (encrinites).

Most probably, the more than $45 \mathrm{~m}$ tall original mound in Caudiel represented some kind of barrier to the currents carrying nutrients, which were trapped mainly by the crinoids that colonized and thrived in the volcanic mound. Once the crinoids died, their remains were reworked by the currents, organizing them in the bioclastic sediments that can be ob- 
served in the surroundings of the volcanic mound (Fig. 15 D, E, F).

\subsection{The Caudiel Fault Zone}

The grid of faults presented in Figure 3 comprises palaeogeographic faults deducted from facies and thickness distribution, and specially for the clear alignment of volcanic deposits. None of these faults has been rejuvenated in later times during the Alpine Orogeny, so they seem to be only actives throughout the basin stage, previous to the tectonic inversion carried out along the Tertiary.

These faults, and specifically the Caudiel Fault, acted as extensional elements in the context of the general extensional or transtensional environment of the Mesozoic. New zones of extension formed during Early and Middle Jurassic in the southern margin of the Eurasian Plate, the northern Gondwana and the Eastern margin of Iberia.

The propagation of the Central Atlantic Ocean, producing the eastward movement of Africa relative to Iberia-Europe, and the early stages of the opening of the Ligurian Tethys, near eastern Iberia (Schettino and Turco, 2011), contributed to the fracturing of the areas located close to the oceans (Fig. 1). These latter constituted favorable sites for the implantation of mantel plumes that gave rise to the magmatic activity recorded in the Caudiel Faul Zone and adjacent areas.

\subsection{Timing of the volcanic deposits}

Accumulation of volcanic deposits generated volcanic edifices that, when they underwent early cementation, represented lasting positive reliefs. They were later covered by onlapping, and logically diachronous, sediments younger than the volcanism. Depending on the elevation of mounds and of the local depositional rates, a significant part of the sedimentary record can be lacking on their summits (Fig. 16). Thus, the Caudiel mound was not covered until the Bathonian in the CA-31 section, even until the Callovian in other sections of the same outcrop. However, in the thinner Sarrión SA.11 and Pina-Barracas PI-BA.1-5 sections, the corresponding mounds were covered in the Bajocian or, in some other sections of this area, in the Bathonian.

For this reason, lateral tracking towards thinning and wedging zones of volcanic mounds are required for biostratigraphical sampling to determine the age of their emplacements. Lateral observations are also important for assessing the overlapping of multi-level lava flows and pyroclastic deposits, and specially to detect sedimentary hiatuses.

Two volcanic levels of different stratigraphic position, relevance and geographical extent, interbedded in the Middle Jurassic carbonate sediments along the Caudiel Fault Zone, have been identified. They are likely corresponding to two distinct volcanic steps.

The epiclastic deposits of the lower level are only located in the PI-BA.3-1 section and surroundings, interbedded be- tween the Casinos and the El Pedregal formations. Below the epiclastics, the beds of the Casinos Formation surely have at least an Opalinum Chronozone age. In the PI-BA.2-4 and other nearby sections, chronorecords of the Murchisonae Chronozone have been identified in beds that underlie the Concavum Chronozone. Based on that, it can be assumed that the Murchisonae Chronozone could have been eroded or not deposited before the volcanic accumulation in the PIBA.3-1 section (Fig. 16). Above the volcanics, the presence of a regional hiatus, including the Bradfordensis and probably the upper part of the Murchisonae chronozones, is congruent with the unconformity intra-Murchisonae that marks the lower boundary of the $2^{\text {nd }}$ order MJ cycle, determined in Fernández-López, (1997a, b), Fernández-López and Gómez (2004), Gómez and Fernández-López (2004a,b; 2006), and Gómez et al. (2004). The stratigraphic emplacement of the lower volcanic level of the Middle Jurassic along the Caudiel Fault Zone could be placed, with a reasonable guarantee, into the Murchisonae Chronozone.

Respect to the upper volcanic level, considering the carbonates located below the volcanic deposits, in six of the described successions (Caudiel CA-1 and CA-31 sections and Pina-Barracas PI-BA.1-5, PI-BA.1-7, PI-BA.2-4 and PIBA.3-1 sections), the time distribution of the ammonite taxa are not younger than the Concavum Chronozone of the Late Aalenian (Fig. 16). In section SA.3-1 of the Sarrión.3 outcrop, only chronorecords of the Bradfordensis Chronozone of the Late Aalenian have been found below the volcanic deposits. Probably there is a hiatus affecting the Concavum Chronozone. By contrast, in section SA.1-1 of the Sarrión outcrop, the carbonates located immediately below the volcanic deposits contain chronorecords diagnostic of the Discites Chronozone of the Early Bajocian.

Regarding the carbonates located above the volcanics, the best dated sections, having the thinnest volcanic deposits, reveal that the Discites Chronozone is present in some of the sections (PI-BA.2-4 and SA.2-1) and probably in others, like in the CA-1 section. The assemblage of Haplopleuroceras, Eudmetoceras and Fontannesia, with resedimented elements of Haplopleuroceras above the volcaniclastic materials in the CA-1 section, is not diagnostic of a specific chronozone. This assemblage can be considered indicative of both the latest Concavum Chronozone of the Late Aalenian and/or the earliest Discites Chronozone of the Early Bajocian.

As can be seen, in most of the stratigraphic sections (CA1, CA-31, PI-BA.1-5, PI-BA.1-7, PI-BA.2-4 and PI-BA.3-1), the sediments located immediately below the volcanic deposits are Late Aalenian Concavum Chronozone in age, whilst the sediments located above the thinest peripheral volcanics contain ammonites of the Early Bajocian Discites Chronozone. Consequently, the age of the volcanism can be placed around the Aalenian-Bajocian transition. Nevertheless, in the Caudiel outcrop, the possibility that the volcanism could have an intra-Concavum Chronozone age cannot be excluded. In the Sarrión. 1 and Sarrión. 2 outcrops, the volcanism is a bit 

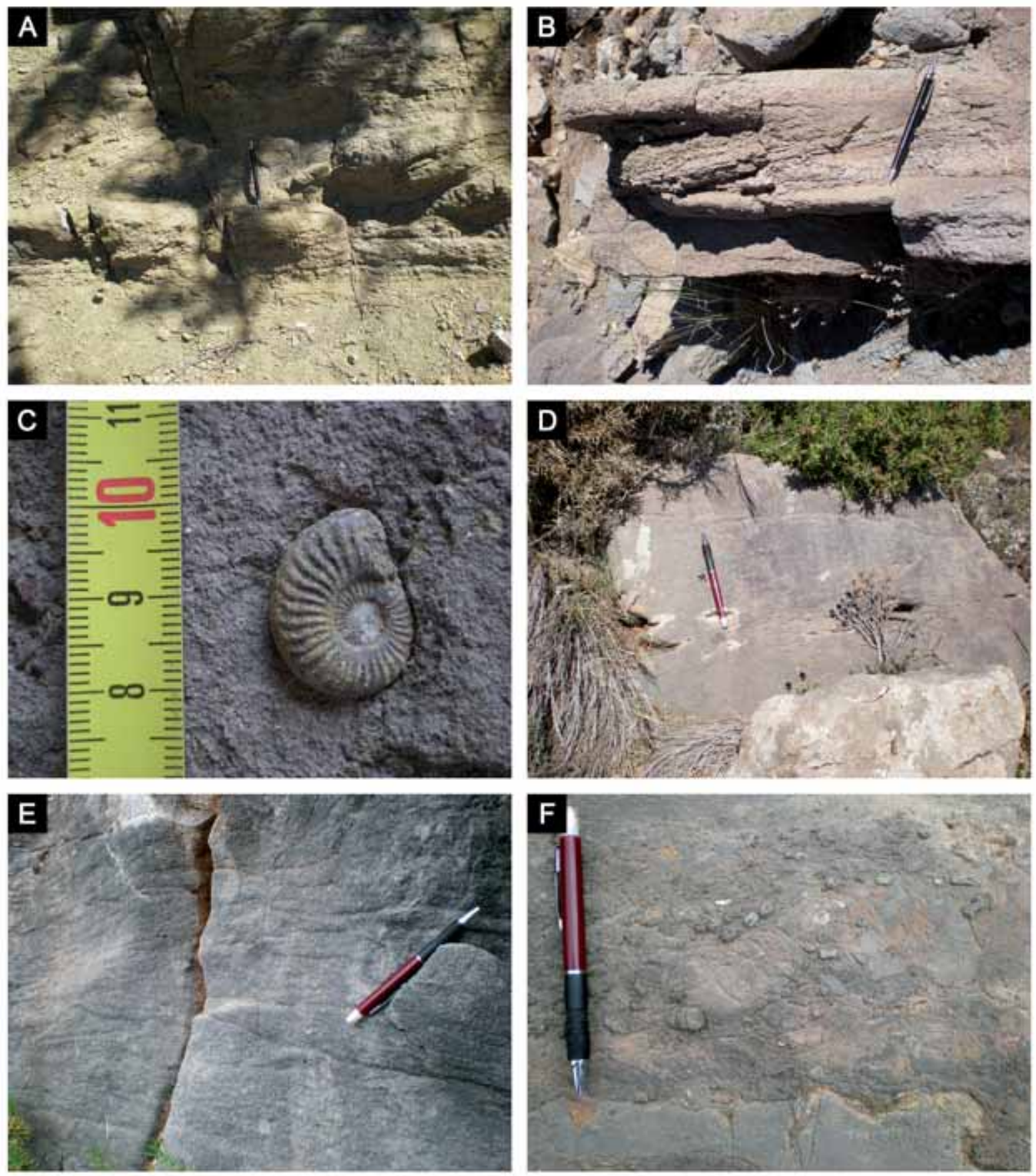

Fig. 15.- A and B) Epiclastic deposits showing cross-bedding induced by currents. C) Well preserved internal mould of ammonites fossilized in the epiclastic deposits of photo B). Internal chambers of the shell are filled with calcitic cement, but the external chambers are filled-up with fine volcanic particles. D, E and F) Echinoderm wackestone to grainstone limestones located on the flanks and the base of the slope of the volcanic mound in the Caudiel outcrop. D) Echinoderm packstone-grainstone deposited over its northern flank. Crinoids were the main organisms colonizing the Caudiel volcanic mound and are the chief components of the surrounding carbonate deposits. E) Crinoidal limestone showing bioclastic rills constituted by remains of crinoids. F) Detail of echinoderm-rich wackestone-packstone with crinoids concentrated in rills. Notice the hardgrounds with bioturbation and early cementation indicative of interruptions in the deposition of carbonates over relatively long periods. Pen for scale is $14 \mathrm{~cm}$ long.

younger, of a Discites Chronozone age, indicating that, within the resolution provided by the biostratigraphical data, there is some slight diachroneity between the different outcrops. The age of volcanism in the SA.3-1 section is uncertain, but, taking into account the regional data, an Aalenian-Bajocian transition age could be assumed.
In summary, it could be admitted that the stratigraphic emplacement of the local lower volcanic phase of the Middle Jurassic along the Caudiel Fault Zone occurred during the Aalenian, roughly coincident with the lower boundary of the MJ-1 sedimentary cycle. The upper volcanic phase was slightly diachronous. It took place in most areas around the 
Aalenian-Bajocian transition and locally (in Sarrión.1 and Sarrión.2 outcrops), shortly after, in the earliest Bajocian (earliest Discites Chronozone), during the deepening stage of the MJ-1 facies cycle (Figs.4 and 16).

\subsection{Age of the volcanism}

Volcaniclastic submarine deposits are susceptible to be reworked by marine agents following cessation of the volcanic activity or even during their deposition (Sorrentino et al., 2011). Therefore, it might be thought that reworked volcanics could have been repositioned on younger stratigraphic sites than the primary emplacements, specially where synsedimentary tectonic acted. A possible scenario of this is one whereby subsiding blocks, characterized by active sedimentation, would be intermittently receiving volcanic products that come from the dismantling of volcanic mounds, located on static or lifted neighbouring blocks in which erosion predominates. That way, there could be a discrepancy between the age of the primary volcanism and the timing of the final stratigraphic positioning of their reworked deposits.

Volcaniclastic edifices could be completely eroded and the epiclastic submarine residues may be the only evidence of submarine volcanic activity (Sorrentino et al., 2014). In contrast, no edifices having relevant positive depositional relief can be entirely formed of reworked epiclastic deposits (White et al, 2003).

Early cementation contributes to the preservation of the volcanic edifices, as evidenced in the Caudiel outcrop (Gómez, 1979; Fernández-López et al., 1985, and Fig. 16), as well as in the Pina-Barracas.1, Sarrión.1 and Sarrión.2 outcrops (Figs. 8,11 and 16). Flanks and summit of the volcanic mounds are later gradually covered by onlapping younger carbonate sedimentary successions. The presence of these volcanic mounds is consequently a proof of the primary volcanic accumulation and, hence, there is no doubt that their stratigraphic position coincides with the age of the volcanic process. Instead, the residual product, which arises as a result of the full or partial dismantling of a nearby edifice, may be either of the same age or younger than the source deposits.

In the PI-BA.2-4 and SA.3-1 sections, the volcanic intercalations of the uppermost magmatic phase are entirely epiclastic layers, which could be the result of edifices that were totally destroyed, of segments laterally detached from large volcanic piles, or even the border of primary volcanic mounds preserved in the subsoil. Nevertheless, since the stratigraphic position of isolated and flattened epiclastic levels closely matches with the stratigraphic position of the primarily accumulated volcanic mounds in other localities along the Caudiel Fault Zone, it can be accepted that the stratigraphic age of

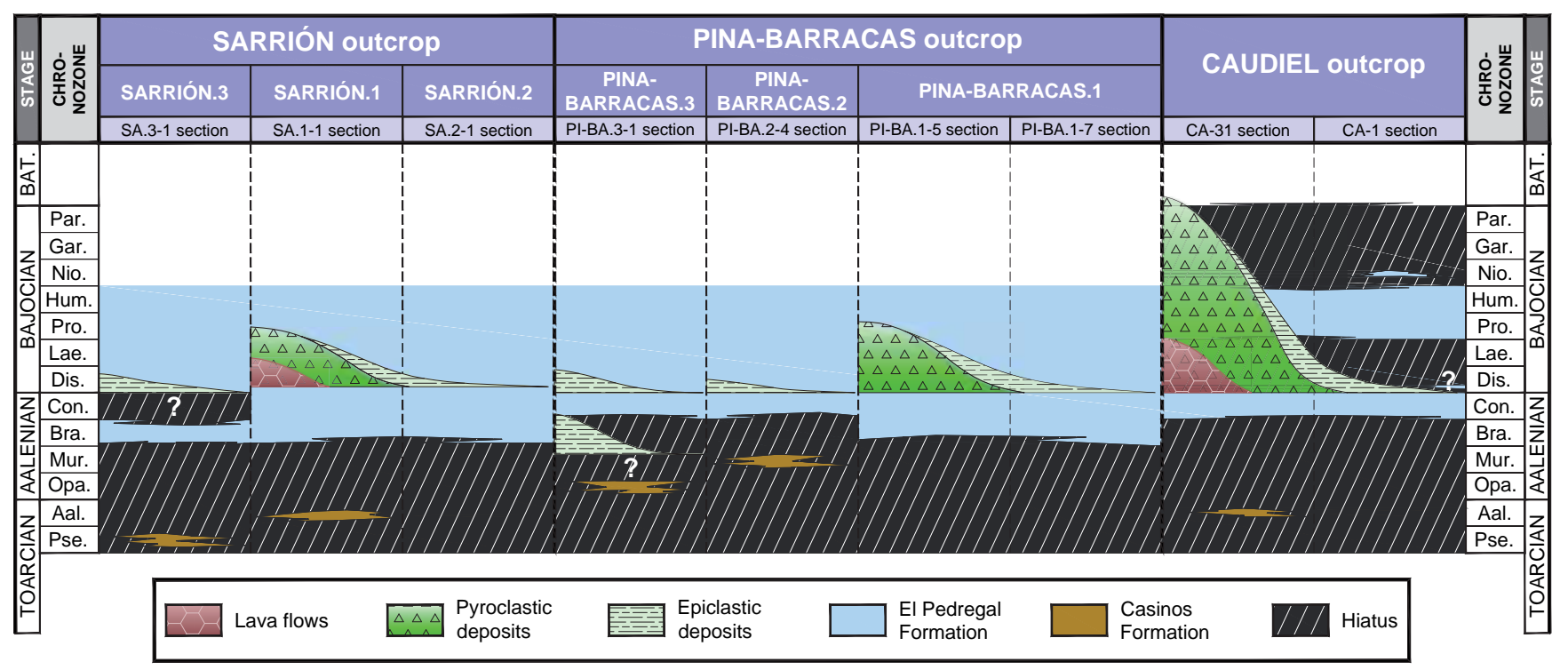

Fig. 16.- Chronostratigraphical distribution of the volcanic deposits in the studied sections along the Caudiel Fault Zone. In the Caudiel and Pina-Barracas outcrops, the sediments located immediately below the volcanic deposits included into the El Pedregal Formation are Late Aalenian Concavum Chronozone in age, whilst the sediments located above the thin volcanic or epiclastic deposits characterize the Early Bajocian Discites Chronozone. The age of the volcanism can be positioned around the Aalenian-Bajocian transition. However, in the Caudiel outcrop, an age intra-Concavum Chronozone for the volcanism cannot be discarded. In the Sarrión.1 and Sarrión.2 outcrops, the volcanism has a Discites Chronozone age, a bit younger, indicating a slight diachroneity between the different outcrops. The age of volcanism in the SA.3-1 section is uncertain because the hiatus located below the volcanic deposits, but, taking into account the regional data, an AalenianBajocian transition age could be assumed. Another lower smaller volcanism was recorded during the Murchisonae Chronozone only in the Pina-Barracas. 3 outcrop. It should be noted that the thickness drawn for the volcanic levels is not representative of the real thickness, but rather of the chronozonal extent. Abbreviations: Pse-Pseudoradiosa, Aal-Aalensis, Opa-Opalinum, Mur-Murchisonae, Bra-Bradfordensis, Con-Concavum, Dis-Discites, Lae-Laeviuscula, Pro-Propinquans, Hum-Humphriesianum, Nio-Niortense, Gar-Garantiana, Par-ParkinSoni, BAT-BATHONIAN. 
the epiclastic deposits virtually coincides or nearly coincides with the age of the emission of these igneous materials.

It has been considered that all the volcanic mounds were accumulated in single eruptions carried out in a short period of time, as not signals of depositional breaks have been found. If interruptions in the volcanic activity occurred, they were of such a short duration that did not offer possibilities to the sedimentation to separate the different periods of volcanic activity. The general lack of intercalated calcareous beds attests to this and also allows inferring an early cementation. As can be seen in Fig. 16, their size and the sedimentary hiatuses will be key to be covered by sediments of different age.

Concerning the lowermost volcanic level: 1) It is composed of epiclastic deposits, without lava flows, 2) It is restricted to only one area, the Pina-Barracas.3 outcrop, and 3) Large stratigraphic hiatuses over the Late Toarcian and Early Aalenian have been evidenced in this region. As a consequence, determination of the age of the lower epiclastic deposit is difficult and the age of the volcanic event is uncertain. However, stratigraphic emplacements of this age have been recorded in outcrops of the northern part of the Teruel Fault Zone, where extensive primary pyroclastic deposits have been observed.

\subsection{Comparison with the volcanism in other neighbor basins}

Middle Jurassic volcanic deposits are not unique in the Iberian Range. Basaltic volcanic rocks are also common in the Median Subbetic domain of the Betic Ranges of South Spain (i.e. García-Yebra et al., 1972; Vera, 1979; García-Hernández et al., 1980; Vera, 1988; Molina et al, 1998; Molina and Vera, 2001; Vera, 2001; Puga et al., 2004).

Even there are few works dealing with the precise biostratigraphical dating of the volcanic activity in the Betic realm, a study carried out by García-Yebra et al. (1972) dated the eruptions of the Algarinejo-Lojilla region in the Granada province as Aalenian Murchisonae and Concavum chronozones. Other works coincide in stating that the magmatic activity in the Subbetic domain of the Betic Cordillera peaked mainly around the Aalenian-Bajocian (Molina et al., 1998; Molina and Vera, 2001; Vera, 2001; Puga et al., 2004). As can be seen, this age interval is rather coincident with the timing of the Middle Jurassic volcanic deposits located along the Caudiel Fault Zone and included into the El Pedregal Formation of the Iberian Basin. In addition, the Aalenian Murchisonae Chronozone age of the lower igneous event in the Algarinejo-Lojilla region (Betic Ranges) also matches with the age of the lower volcanic level in the Pina-Barracas.3 outcrop of the Iberian Range. These facts indicate that a wide magmatic activity in the eastern and southern parts of the Iberian Plate occurred at this time.

Jurassic magmatic events have also been reported in other parts of Europe like in Sicily (Basilone et al., 2010, 2014), in the $164 \pm 3$ Ma volcanism of the Dinaride (Mikes et al., 2009), in the Crimea Mountains (Pecherskiy et al., 1991; Meijers et al., 2010), in the Transbaikalia regions of Russia (Stupak et al., 2016), as well as in Northern and Central America (i.e. Kowalis et al., 2001; Rubio-Cisneros and Lawton, 2011; Buchs et al., 2013). This active volcanism supports the idea that plate tectonics in both, the Atlantic and the Tethysian margins of the Iberian Plate, maintained a significant activity during the Jurassic.

\section{Conclusions}

Extensional or transtensional faulting, linked to the propagation of the Central Atlantic and the Ligurian Tethys opening, generated a NW and NE trending fault system that conditioned facies and thickness distribution. These faults also favoured the implantation of mantel plumes and associated volcanism, giving rise to the evolution from a magma-poor passive margin, during the latest Triassic to the Pliensbachian, to a magma-rich passive margin, which happened from the Pliensbachian to the Bajocian.

Two stages of submarine volcanic activity, following the NW trending Caudiel Fault Zone, were developed in the southeastern part of the Iberian Plate at the onset of the Middle Jurassic. The lower volcanic level represents a vestigial residue of a potential volcanic phase, having a quite confined geographical extent. Its age can be placed in the Aalenian Murchisonae Chronozone, coinciding with the lower boundary of the MJ-1 cycle.

By contrast, there is no doubt that the upper volcanic level represents a phase of primeval volcanism. Detailed biostratigraphical sampling and study of the carbonates located below and above the volcanic deposits allowed to precise the age of the emplacement of these submarine volcanoes around the boundary between the Late Aalenian Concavum Chronozone and the Early Bajocian Discites Chronozone. Nevertheless, given the resolution provided by the biostratigraphical data, some slight diachronism is recognized.

Since volcanic mounds are indicatives of primary volcanism, and the stratigraphical position of the isolated epiclastic layers coincides with theirs, it can be thought that the stratigraphical age of all volcanic deposits is in accordance with the age of the emission of these igneous rocks.

The timing of this igneous phase in the Iberian Basin matches fairly well with the peak magmatic recorded in the Betic Basin of Southern Spain, supporting the idea that an important volcanic activity occurred during this time interval.

\section{Acknowledgements}

Thanks to Prof. Sixto Fernández-López, Prof. Antonio Goy and Prof. Soledad Ureta of the Departamento de Paleontología of the Facultad de Ciencias Geológicas of the Universidad Complutense de Madrid for the taxonomical determination of the ammonite specimens. Thanks to editor and two anonymous referees for their valuable comments and 
suggestions that considerably improved the original manuscript. This research work was financed by projects CGL 2011-25894 and CGL2011-23947 (MICINN) of the Spanish Ministerio de Economía y Competitividad, and by projects GR3/14/910431, and GI 910429 of the Universidad Complutense de Madrid. The present paper constitutes a part of the PhD Thesis of one of the authors (J.E. Cortés).

\section{References}

Abril, J., García, F., González, F., Iglesias, M., Ortí, F., Rubio, J. (1975): Hoja geológica num. 638 (Alpuente). Mapa Geológico de España E. 1:50 000. Segunda serie, I.G.M.E., Madrid.

Abril, J., Apalategui, O., Ferreiro, E., García, F., González, F., Hernández, E., Lago, E., Ortí, F., Pliego, D.V., Quintero, I., Rubio, J. (1978): Hoja geológica num. 613 (Camarena de la Sierra). Mapa Geológico de España E. 1:50 000. Segunda serie, I.G.M.E., Madrid.

Adrover, R., Aguilar, M.J., Alberdi, M.T., Aragonés, E., Aznar, J.M., Comas, M.J., Gabaldón, V., Giner, J., Godoy, A., Goy, A., Gutierrez Elorza, M., Leal, M.C., Moissenet, E., Olivé, A., Portero, J.M., Ramírez, J.I., Ramírez del Pozo, J. (1983): Hoja geológica num. 590 (La Puebla de Valverde). Mapa Geológico de España E. 1:50 000. Segunda serie, I.G.M.E., Madrid.

Allen, S.R., McPhie, J. (2000): Water-settling and resedimentation of submarine rhyolitic pumice at Yali, eastern Aegean, Greece. Journal of Volcanology and Geothermal Research 95, 285-307. doi: 10.1016/ S0377-0273(99)00127-4.

Ancochea, E., Muñoz, M., Sagredo, J. (1988): Identificación geoquímica del volcanismo Jurásico de la Cordillera Ibérica. Geociências, Aveiro 3(1-2), 15-22.

Bakx, L.A.J. (1935): La géologie de Cascante del Río et de Valacloche (Espagne). Leidsche Geologische Mededeelingen 7(2), 157-220.

Bally, A.W., 1982. Musings over sedimentary basins evolution. In: P. Kent, M.H.P. Botts, D.P. McKenzie, C.A. Williams (eds.), Evolution of Sedimentary Basins. Philosophical Transactions of the Royal Society of London, Mathematical and Physical Sciences 305, 325-328.

Basilone, L., Lena, G., Morticelli, M.G., (2014): Synsedimentarytectonic, soft-sediment deformation and volcanism in the rifted Tethyan margin from the Upper Triassic-Middle Jurassic deep-water carbonates in Central Sicily. Sedimentary Geology 308, 73-69. doi: 10.1016/j.sedgeo.2014.05.002.

Basilone, L., Morticelli, M.G., Lena, G. (2010): Mesozoic tectonics and volcanism of Tethyan rifted continental margins in western Sicily. Sedimentary Geology 226, 54-70. doi: 10.1016/j.sedgeo.2010.02.009.

Buchs, D.M., Pilet, S., Cosca, M., Flores, K.E., Bandini, A.N., Baumgartner, P.O. (2013): Low volume intraplate volcanism in the Early/Middle Jurassic Pacific basin documented by accreted sequences in Costa Rica. Geochemistry, Geophysics, Geosystems 14(5), 1552-1568. doi: 10.1002/ggge.20084.

Callomon, J.H. (2003): The Middle Jurassic of western and northern Europe: its subdivisions, geochronology and correlations. Geological Survey of Denmark and Greenland Bulletin 1, 61-73.

Campos, C., González, F., Goy, A., Lazuen, J., Martín, P., Ortí, F. (1977): Hoja geológica num. 639 (Jérica). Mapa Geológico de España E. 1:50 000. Segunda serie, I.G.M.E., Madrid.

Cas, R.A.F., Wright, J.V. (1987): Volcanic successions. Modern and ancient. Chapman \& Hall, 528 p. doi: 10.1007/978-94-009-3167-1

Fernández-López, S. (1984a): Nuevas perspectivas de la Tafonomía evolutiva: tafosistemas y asociaciones conservadas. Estudios Geológicos 40, 215-224. doi: 10.3989/egeol.84403-4662.

Fernández-López, S. (1984b): Criterios elementales de reelaboración tafonómica en ammonites de la Cordillera Ibérica. Acta Geológica
Hispánica 19(2), 105-116.

Fernández-López, S. R. (1985): El Bajociense en la Cordillera Ibérica. I.- Taxonomía y Sistemática (Ammonoidea). II.- Bioestratigrafía. III.Atlas. Ph. D. Thesis, Departamento de Paleontología, Universidad Complutense. Madrid, $850 \mathrm{p}$.

Fernández-López, S. (1997a): Ammonites, ciclos tafonómicos y ciclos estratigráficos en plataformas epicontinentales carbonáticas. Revista Española de Paleontología 12(2), 151-174.

Fernández-López, S. (1997b): Ammonites, taphonomic cycles and stratigraphic cycles in carbonate epicontinental platforms. Cuadernos de Geología Ibérica 23, 95-136.

Fernández-López, S., Gómez, J.J. (1990): Evolution tectono-sédimentaire et genèse des associations d'ammonites dans le secteur central du Bassin Ibérique (Espagne) pendant l'Aalénien. Cahiers de l'Université Catholique de Lyon, Série Scientifique 4, 39-52.

Fernández-López, S., Gómez, J.J. (2004):The Middle Jurassic eastern margin of the Iberian platform system (Eastern Spain). Palaeogeography and biodispersal routes of ammonoids. Rivista Italiana di Paleontologia e Stratigrafia 110, 151-162. doi: 10.13130/2039-4942/6281.

Fernández-López, S., Mouterde, R. (1994): L'Horizon à Gervillii (Bajocien inférieur) de Tendron (Cher, France). Taphonomie et populations d'ammonites. Proceedings 3rd International Meeting on Aalenian and Bajocian Stratigraphy. Miscellanea del Servizio Geologico Nazionale $5,117-159$

Fernández-López, S., Gómez, J.J., Goy, A. (1985): Sédimentologie des carbonates développés sur un "monticule" de matériaux volcaniques. In: J. Canerot, A. Goy (eds.), Le Jurassique des Ibérides Orientales (Espagne). Strata, serie 2: mémoires, vol. 2, pp. 101-115.

Franke, D. (2013): Rifting, lithosphere breakup and volcanism: Comparison of magma-poor and volcanic rifted margins. Marine and Petroleum Geology 43, 63-87. doi: 10.1016/j.marpetgeo.2012.11.003.

García-Frank, A. (2006): Evolución biosedimentaria y secuencial del Jurásico Medio inferior en la Cuenca Ibérica (Sector NO). Ph. D. Thesis, Departamento Paleontología, Universidad Complutense. Madrid, $529 \mathrm{p}$.

García-Frank, A., Ureta, S., Mas, R. (2006): Tectonically active Aalenian in the northwestern Iberian Basin (Spain). $7^{\text {th }}$ International Congress on the Jurassic System. Poland-Kraków, 6-18 de septiembre. Libro de resúmenes, Volumina Jurassica IV, 42.

García-Frank, A., Ureta, S., Mas, R. (2008): Aalenian pulses of tectonic activity in the Iberian Basin, Spain. Sedimentary Geology 209(1-4), 15-35. doi: 10.1016/j.sedgeo.2008.06.004.

García-Hernández, M., López-Garrido, A.C., Rivas, P., Sanz de Galdeano, C., Vera, J.A. (1980): Mesozoic palaeogeographic evolution of the External Zones of the Betic Cordillera. Geologie en Mijnbouw 59(2), 155-168.

García-Yebra, R., Rivas, P., Vera, J.A. (1972): Precisiones sobre la edad de las coladas volcánicas jurásicas en la región Algarinejo-Lojilla (Zona Subbética). Acta Geológica Hispánica VII (5), 133-137.

Gautier, F. (1968): Sur l'existence et l'age d'un paléovolcanisme dans le Jurassique sud-aragonais (Espagne). Comptes Rendus de la Société Géologique de France 3, 74-75.

Gautier, F. (1974): Hoja geológica num. 614 (Manzanera). Mapa Geológico de España E. 1:50 000. Segunda serie, I.G.M.E., Madrid.

Geoffroy, L., Burov, E.B., Werner, P. (2015): Volcanic passive margins: another way to break up continents. Scientific Reports, 5, 14828. doi: 10.1038/srep14828.

Gillespie, M.R., Styles, M.T. (1999): BGS Rock classification scheme. Volume 1. Classification igneous rocks. British Geological Survey Research Report (2 $2^{\text {nd }}$. Edition), $52 \mathrm{p}$.

Gómez, J.J. (1979): El Jurásico en facies carbonatadas del sector levantino de la Cordillera Ibérica. Seminarios de Estratigrafía. Serie Monografías, num. 4. Universidad Complutense, Consejo Superior de Investigaciones Científicas, Madrid, 683 p. 
Gómez, J.J. (1985a): Sedimentología y paleogeografía del Jurásico en la hoja geológica num. 55 (Llíria). Mapa Geológico de España E. 1:200 000. I.G.M.E., Madrid, pp. 37-60.

Gómez, J.J. (1985b): Sedimentología y paleogeografía del Jurásico Inferior y Medio en la hoja geológica num. 47 (Teruel). Mapa Geológico de España E. 1:200 000. I.G.M.E., Madrid, pp. 47-72.

Gómez, J.J., Fernández-López, S. (2004a): Las unidades litoestratigráficas del Jurásico Medio de la Cordillera Ibérica. Geogaceta 35, 91-94.

Gómez, J.J., Fernández-López, S. (2004b): Jurásico Medio. In: J.A. Vera, (ed.) Geología de España. SGE-IGME, Madrid, pp. 500-503.

Gómez, J.J., Fernández-López, S. (2006): The Iberian Middle Jurassic carbonate-platform system: Synthesis of the palaeogeographic elements of its eastern margin (Spain). Palaeogeography, Palaeoclimatology, Palaeoecology 236, 190-205. doi: 10.1016/j.palaeo.2005.11.008.

Gómez, J.J., Goy, A. (1977): Estudio de las facies relacionadas con un montículo de origen volcánico en el Jurásico Medio de Caudiel (Castellón). Resúmenes VIII Congreso Nacional de Sedimentología, Oviedo-León.

Gómez, J.J., Goy, A. (1979): Las unidades litoestratigráficas del Jurásico medio y superior, en facies carbonatadas del Sector Levantino de la Cordillera Ibérica. Estudios Geológicos 35, 569-598.

Gómez, J.J., Goy A. (2005): Late Triassic and Early Jurassic palaeogeographic evolution and depositional cycles of the Western Tethys Iberian platform system (Eastern Spain). Palaeogeography, Palaeoclimatology, Palaeoecology 222, 77-94. doi: 10.1016/j.palaeo.2005.03.010.

Gómez, J.J., Comas-Rengifo, M.J., Goy, A. (2003): Las unidades litoestratigráficas del Jurásico Inferior de las Cordilleras Ibérica y Costeras Catalanas. Revista de la Sociedad Geológica de España 16(3-4), 227238.

Gómez, J.J., Trell, A., Pérez, P. (1976): Presencia y edad de vulcanitas en el Jurásico del Norte de Valencia (Cordillera Ibérica, España). Acta Geológica Hispánica XI(1), 1-7.

Gómez, J.J., Fernández-López, S., Goy A. (2004): Primera fase de postrifting: Jurásico Inferior y Medio. In: J.A. Vera, (ed.) Geología de España. SGE-IGME, Madrid, pp. 495-503.

Goy, A., Gómez, J.J., Yébenes, A. (1976): El ]urásico de la Rama Castellana de la Cordillera Ibérica (Mitad Norte). I. Unidades litoestratigráficas. Estudios Geológicos 32, 391-423.

Goy, A., Comas-Rengifo, M.J., Arias, C., García-Joral, F., Gómez, J.J., Herrero, C., Martínez, G., Rodrigo A. (1997): El tránsito Pliensbachiense/Toarciense en el sector central de la rama aragonesa de la Cordillera Ibérica (España). Cahiers de l'Université Catholique de Lyon 10, 159-179.

Kokelaar, B.P. (1982): Fluidization of wet sediments during the emplacement and cooling of various igneous bodies. Journal of the Geological Society, London 139, 21-33. doi: 10.1144/gsjgs.129.1.0021.

Kowallis, B.J., Christiansen, E.H., Deino, A.L., Zhang, Ch., Everett, B.H. (2001): The record of Middle Jurassic volcanism in the Carmel and Temple Cap Formations of southwestern Utah. Geological Society of America Bulletin 113(3), 373-387. doi: 10.1130/0016-7606(2001)113<0373:TROMJV>2.0.CO;2.

Lago, M., Arranz, E., Pocoví, A., Martínez, R.M., Gil-Imaz, A., Valenzuela-Ríos, J.I., García, J. (1996): Contribución de los magmatismos presentes en la Comunidad Autónoma de Aragón al Patrimonio Geológico. Geogaceta 20(5), 1175-1176.

Lago, M., Arranz, E., Gil, A., Pocoví, A. (2004): Magmatismo asociado. In: J.A. Vera, (ed.) Geología de España. SGE-IGME, Madrid, pp. 522-525.

Martin, R. (1936): Die geologie von Camarena de la Sierra und Riodeva (Provinz Teruel, Spanien). Leidsche Geologische Mededeelingen 8(1), 55-154.

Martínez, R.M., Lago, M., Valenzuela, J.I., Vaquer, R., Salas, R. (1996a): El magmatismo alcalino jurásico del sector SE de la Cadena Ibérica: Composición y estructura. Geogaceta 20(7), 1687-1690.
Martínez, R.M., Lago, M., Vaquer, R., Arranz, E., Valenzuela, J.I. (1996b): Precisiones terminológicas entre mecanismos de fragmentación y emplazamiento de rocas volcanoclásticas. Geogaceta 20(3), 515-517.

Martínez, R.M., Lago, M., Vaquer, R., Valenzuela, J.I., Arranz, E. (1996c): Composición mineral del volcanismo jurásico (pre-Bajociense medio) en la Sierra de Javalambre (Cordillera Ibérica, Teruel): Datos preliminares. Geogaceta 19, 41-44.

Martínez, R., Valenzuela, J.I., Lago, M., Vaquer, R., Arranz, E. (1996d): Las rocas volcanoclásticas jurásicas de Albentosa-1 (Cordillera Ibérica, Teruel): Mecanismos de fragmentación y emplazamiento. Geogaceta $19,45-46$.

Martínez, R.M., Lago, M., Valenzuela, J.I., Vaquer, R., Salas, R., Dumitrescu, R. (1997a): El volcanismo Triásico y Jurásico del sector SE de la Cadena Ibérica y su relación con los estadios de rift mesozoicos. Boletín Geológico y Minero 108-4 and 5 (367-376), 39-48.

Martínez, R.M., Valenzuela, J.I., Lago, M., Bastida, J., Vaquer, R. (1997b): Origen epiclástico de estratificaciones cruzadas afectando a materiales volcanoclásticos jurásicos en la Sierra de Javalambre (Teruel). Cuadernos de Geología Ibérica 22, 121-137.

Martínez, R.M., Vaquer, R., Lago, M. (1998): El volcanismo jurásico de la Sierra de Javalambre (Cadena Ibérica, Teruel). Teruel 86(1), 43-61.

Martínez-González, R.M., Lago, M., Valenzuela-Ríos, J.I., Arranz, E. (1996): Interés como Patrimonio Geológico de dos magmatismos mesozoicos en la Sierra de Javalambre (Teruel). Geogaceta 20(5), 11861188 .

Meijers, M.J.M., Vrouwe, B., van Hinsbergen, D.J.J., Kuiper, K.F., Wijbrans, J. Davies, G.R., Stephenson, R.A., Kaymackci, N., Matenco, L., Saintot, A. (2010): Jurassic arc volcanism on Crimea (Ukraine): Implications for the paleo-subduction zone configuration of the Black Sea region. Lithos 119(3-4), 412-426. doi: 10.1016/j. lithos.2010.07.017.

Mikes, T., Baresel, B., Kronz. A., Frei, D., Dunkl, I., Tolosana-Delgado, R., von Eynatten, H. (2009): Jurassic granitiod magmatism in the Dinaride Neotethys: geochronological constraints from detrital minerals. Terra Nova 21(6), 495-506. doi: 10.1111/j.13653121.2009.00.00907.x.

Molina, J.M., Vera, J.A. (2001): Interaction between sedimentation and submarine volcanism (Jurassic, Subbetic, southern Spain). Geogaceta $29,142-145$.

Molina, J.M., Vera, J.A., De Gea, G. (1998): Vulcanismo submarino del Santoniense en el Subbético: Datación con nannofósiles e interpretación (Formación Capas Rojas, Alamedilla, Provincia de Granada). Estudios Geológicos 54, 191-197. doi: 10.3989/egeol.98545-6218

Nemčok, M. (2016): Rifts and passive margins. Structural architecture, thermal regimes, and petroleum systems. Cambridge University Press, 607 p. doi: 10.1017/cbo9781139198844

Ortí, F. (2004): Últimas etapas de actividad del rifting. Sedimentos asociados. In: J.A. Vera, (ed.) Geología de España. SGE-IGME, Madrid, pp. 492-495.

Ortí, F., Sanfeliu, T. (1971): Estudio del vulcanismo jurásico de Caudiel (Castellón) en relación con procesos de lateritización, condensación y silicificación de la serie calcárea. Instituto de Investigaciones Geológicas de la Diputación Provincial. Barcelona vol. XXVI, 21-34.

Ortí, F., Vaquer, R. (1980): Volcanismo jurásico del sector valenciano de la Cordillera Ibérica. Distribución y trama estructural. Acta Geológica Hispánica 15, 127-130.

Osete, M.L., Gómez, J.J., Pavón-Carrasco, F.J., Villalaín, J.J., PalenciaOrtas, A., Ruiz-Martínez, V.C., Heller, F. (2011): The evolution of Iberia during the Jurassic from palaeomagnetic data. Tectonophysics 502, 105-120. doi: 10.1016/j.tecto.2010.05.025.

Page, K.N. (2003): The Lower Jurassic of Europe: its subdivision and correlation. Geological Survey of Denmark and Greenland Bulletin 1, 23-59. 
Pecherskiy, D.M., Didenko, A.N., Safonoy, V.A., Tikhonov, L.V., Tselmovich, V.A. (1991): Petromagnetic and paleomagnetic characteristics of Middle Jurassic volcanism in the Crimea Mountains. Izvestiya Akademii Nauk SSSR Seriya Geologicheskaya 3, 85-104.

Puga, E., Morata, D., Díaz de Federico, A. (2004): Magmatismo mesozoico y metamorfismo de muy bajo grado. In: J.A. Vera (ed.), Geología de España. SGE-IGME, Madrid, pp. 386-387.

Raos, A.M., McPhie, J. (2003): The submarine record of a large-scale explosive eruption in the Vanuatu Arc: $\sim 1$ Ma Efate Pumice Formation. In: J.D.L. White, J.L. Smelli, D.A. Clague (eds.), Explosive subaqueous volcanism. American Geophysical Union, Geophysical Monograph Series, 140, pp. 273-283. doi: 10.1029/140GM18.

Rubio-Cisneros, I.I., Lawton, T.F. (2011): Detrital zircón U-Pb ages of sandstones in continental red beds at Valle de Huizachal, Tamaulipas, NE Mexico: Record of Early-Middle arc volcanism and transition to crustal extension. Geosphere 7(1), 159-170. doi: 10.1130/ GEOS00567.1.

Salas, R., Casas, A. (1993): Mesozoic extensional tectonics, stratigraphy and crustal evolution during the Alpine cycle of the eastern Iberian basin. Tectonophysics 228, 33-55. doi: 10.1016/0040-1951(93)90213-4.

Salas, R., Guimerà, J., Mas, R., Martín-Closas, C., Meléndez, A., Alonso, A. (2001): Evolution of the Mesozoic Central Iberian Rift System and its Cainozoic inversión (Iberian Chain). In: P.A. Ziegler, W. Cavazza, A.H.F. Robertson, S. Crasquin-Soleau (eds.), Peri-Tethys Memoir 6: Peri-Tethyan Rift/Wrench Basins and Passive Margins. Mémoires du Muséum National d'Histoire Naturelle 186, pp.145-186. Paris.

Sánchez-Moya, Y., Sopeña, A. (2004): El rift mesozoico Ibérico. In: J.A. Vera (ed.), Geología de España. SGE-IGME, Madrid, pp. 484.

Schettino, A., Turco, E. (2011): Tectonic history of the western Tethys since the Late Triassic. Geological Society of America Bulletin 123, 89-105. doi: 10.1130/B30064.1.

Soriano, C., Riggs, N., Giordano, G., Porreca, M., Conticelli, S. (2012): Cyclic growth and mass wasting of submarine Los Frailes lava flow and dome complex in Cabo de Gata, SE Spain. Journal of Volcanology and Geothermal Research 231-232, 72-86. doi: 10.1016/j.volgeores.2012.04.015.

Sorrentino, L., Cas, R.A.F., Stilwell, J.D. (2011): Evolution and facies architecture of Paleogene Surtseyan volcanoes on Chatham Islands, New Zealand, Southwest Pacific Ocean. Journal of Volcanology and Geothermal Research 202, 1-21. doi: 10.1016/j.volgeores.2010.12.013.

Sorrentino, L., Stilwell, J.D., Mays, Ch. (2014): A model of tephra dispersal from an early Palaeogene shallow submarine Surtseyan-style eruption(s), the Red Bluff Tuff Formation, Chatham Island, New Zealand. Sedimentary Geology 300, 86-102. doi: 10.1016/j.sedgeo.2013.12.001.

Stampfli, G.M., Borel, G.D. (2002): A plate tectonic model for the Paleozoic and Mesozoic constrained by dynamic plate boundaries and restored synthetic ocean isochrones. Earth and Planetary Science Letters 196, 17-33. doi: 10.1016/S0012-821X(01)00588-X.

Stampfli, G.M., Borel, G.D. (2004): The TRANSMED transects in space and time: constraints on the paleotectonic evolution of the Mediterranean domain. In: W. Cavazza, F.M. Roure, W. Spakman, G.M. Stampfli, P.A. Ziegler (eds.), The TRANSMED Atlas-The Mediterraean Region from Crust to Mantle. Springer Berlin, Heidelberg, New York, pp. 53-80, and CD-ROM. doi: 10.1007/978-3-642-18919-7_3.

Stampfli, G.M., Hochard, C. (2009): Plate tectonics of the Alpine realm. In: J.B. Murphy, J.D. Keppie, A.J. Hynes (eds.), Ancient orogens and modern analogues. Geological Society, London. Special Publications,
327, pp.89-111. doi: 10.1144/SP327.6.

Stampfli, G.M., Borel, G.D., Marchant, R., Mosar, J. (2002): Western Alps geological constraints on western Tethyan reconstructions. In: G. Rosenbaum, G.S. Lister (eds.), Reconstruction of the evolution of the Alpine-Himalayan Orogen. Journal of the Virtual Explorer 7, pp.75-104. doi: 10.3809/jvirtex.2002.00057.

Stupak, F.M., Kudryashova, E.A., Lebedev, V.A. (2016): On the Jurassic volcanism and on volcanoes in the Shadoron Basin, eastern Transbaikalia. Journal of Volcanology and Seismology 10(2), 86-99. doi: 10.1134/S0742046316020056.

Valenzuela, A., Donaire, T., González-Roldán, M.J., Toscano, M., Pascual, E. (2011): Volcanic architecture in the Odiel river area and the volcanic environment in the Riotinto-Nerva Unit, Iberian Pyrite Belt, Spain. Journal of Volcanology and Geothermal Research 202, 29-46. doi: 10.1016/j.volgeores.2010.12.018.

Valenzuela, J.I., Martínez, R.M., Lago, M. (1996): Nota preliminar sobre la edad del paleovolcanismo jurásico de Javalambre (Cordillera Ibérica, Teruel). Geogaceta 19, 39-40.

Van Wees, J.D., Arche, A., Beijdorff, C.G., López-Gómez, J., Cloetingh, S.A.P.L. (1998): Temporal and spatial variations in tectonic subsidence in the Iberian Basin (eastern Spain): inferences from automated forward modelling in high-resolution stratigraphy (Permian-Mesozoic). Tectonophysics 300, 285-310. doi: 10.1016/S0040-1951(98)00244-3.

Vera, J.A. (1979): VI. Paleogeografía de las zonas externas de las Cordilleras Béticas durante el Jurásico (Introducción). Cuadernos de Geología de la Universidad de Granada 10, 553-556.

Vera, J.A. (1988): Evolución de los sistemas de depósito en el margen ibérico de la Cordillera Bética. Revista de la Sociedad Geológica de España 1(3-4), 373-391.

Vera, J.A. (2001): Evolution of the South Iberian Continental Margin. In: P.A. Ziegler, W. Cavazza, A.H.F. Robertson, S. Crasquin-Soleau (eds.), Peri-Tethys Memoir 6: Peri-Tethyan Rift/Wrench Basins and Passive Margins. Mémoires du Muséum National d'Histoire Naturelle 186, pp. 109-143. Paris.

Waichel, B.L., De Lima, E.F., Sommer, C.A., Lubachesky, R. (2007): Peperite formed by lava flows over sediments: An example from the central Paraná Continental Flood Basalts, Brazil. Journal of Volcanology and Geothermal Research 159, 343-354. doi: 10.1016/j.volgeores.2006.07.009.

White, M.J., McPhie, J. (1997): A submarine welded ignimbrite-crystal-rich sandstone facies association in the Cambrian Tyndall Group, western Tasmania, Australia. Journal of Volcanology and Geothermal Research 76, 277-295. doi: 10.1016/S0377-0273(96)00105-9.

White, J.D.L., McPhie, J., Skilling, I. (2000): Peperite: A useful genetic term. Bulletin of Volcanology 62, 65-66. doi: 10.1007/s004450050293.

White, J.D.L., Smellie, J.L., Clague, D.A. (2003): Introduction: A deductive outline and tropical overview of subaqueous explosive volcanism. In: J.D.L. White, J.L. Smellie, D.A. Clague (eds.), Explosive subaqueous volcanism. American Geophysical Union, Geophysical Monograph Series 140, pp. 1-23. doi: 10.1029/140gm01

Ziegler, P.A. (1990): Geological Atlas of Western and Central Europe. Shell International Petroleum. Maatschappi B.V. Geological Society Publishing House, Bath, pp. 1-239.

Ziegler, P.A., Cloetingh, S., Guiraud, R., Stampfli, G.M. (2001): PeriTethyan platforms: constraints on dynamics of rifting and basin inversion. In: P.A. Ziegler, W. Cavazza, A.H.F. Robertson, S. CrasquinSoleau (eds.), Peri-Tethys Memoir 6: Peri-Tethyan Rift/Wrench Basins and Passive Margins. Mémoires du Muséum National d'Histoire Naturelle 186, pp.9-49. Paris. 